\title{
IZDVOJENO MIŠLJENJE U SUDSKIM POSTUPCIMA I PRAKSA USTAVNOG SUDA REPUBLIKE HRVATSKE
}

Dr. sc. Teodor Antić, dipl. iur.

Ustavni sud Republike Hrvatske
UDK: 347.991

347.92

Ur.: 27. travnja 2016.

Pr.: 21. lipnja 2016.

Izvorni znanstveni rad

„Kad svi misle isto, znači da nitko ne misli mnogo. “

Walter Lippmann

\begin{abstract}
Sažetak
Predmet ovoga članka pravni je institut izdvojenog mišljenja suca koji se ne slaže s odlukom za koju je glasovala većina sudaca kolegijalnoga sudskog tijela, bilo da je riječ o njezinoj izreci ili o obrazloženju. Iako se mogućnost izdvajanja mišljenja tradicionalno smatra obilježjem država commom law sustava, ona danas postoji $i$ u većini država kontinentalnog sustava, osobito na ustavnim sudovima. Izdvojeno mišljenje obrađuje se s povijesnokomparativnog i pravno-teorijskog aspekta. Ukazuje se na razloge u prilog dopuštanja izdvajanja mišljenja kao što su sloboda izražavanja mišljenja $i$ sudačka neovisnost, ali i protiv toga, primjerice pravna sigurnost, jasnoća $i$ uvjerljivost sudskih odluka te utjecaj na integritet $i$ ugled suda. U hrvatskom pravnom sustavu u redovitom sudovanju izdvojena mišljenja u pravilu su dopuštena, ali ne i njihova objava, dok je na Ustavnom sudu izričito dopušteno izdvajanje mišljenja $i$ obrazlaganje suprotnoga glasovanja kao $i$ njihovo objavljivanje. Praksa Ustavnog suda, međutim, pokazuje priličnu suzdržanost ustavnih sudaca u korištenju te mogućnosti.
\end{abstract}

Ključne riječi: sudska odluka, izdvojeno mišljenje, suprotni glas, ustavni sud.

\section{UVOD}

Sudske odluke donosi sudac pojedinac ili kolektivno sudsko tijelo sastavljeno od više sudaca (sudsko vijeće). U pravilu sudac pojedinac provodi postupak i donosi odluku na sudovima prvog stupnja i u manje složenim predmetima, dok u složenijim predmetima i na višim sudovima to čine sudska vijeća. Odlučivanje u vijeću provodi se radi osiguranja svestranog razmatranja činjeničnih i pravnih aspekata slučaja 
kako bi se sudskoj odluci dao odgovarajući dignitet i strankama odaslala poruka da je sudska odluka u konkretnom slučaju rezultat pravne ocjene više sudaca što joj daje posebnu težinu i autoritet. U tom smislu u sudskim postupcima od posebne je važnosti usuglašavanje mišljenja sudaca koji čine sudsko vijeće.

Donošenje sudske odluke složen je proces, osobito kad je riječ o predmetima u kojima odlučuje sudsko vijeće. Na njezin sadržaj i kvalitetu utječe niz procesa i odnosa unutar suda kao i između samih sudaca koji sudjeluju u njezinu donošenju. Sudsko vijeće unutar sebe može istodobno sadržavati pojedine elemente homogene grupe (isto formalno obrazovanje, isti ili slični interesi, znanja i dr.) i pojedine elemente heterogene grupe (različiti interesi, znanja, sposobnosti, stil, karakter i dr.). Suci koji čine vijeće nemaju nužno jednaku razinu teorijskog znanja, praktičnih vještina i životnog iskustva. Stoga je u radu sudskog vijeća realno očekivati razlike između pojedinih članova u razumijevanju činjenica i tumačenju pravnih normi, što zahtijeva ozbiljnu profesionalnu raspravu i usuglašavanje radi postizanja konsenzusa ili barem minimalne razine njihove suglasnosti potrebne za donošenje odluke (u pravilu natpolovična većina svih članova vijeća) kao temeljnog obilježja kolektivnog odlučivanja. U tom smislu sudska odluka često je zapravo izraz mišljenja većine koja je za nju glasovala, a glasovanje odnosno stajalište svakoga pojedinog suca - člana sudskog vijeća nije poznato javnosti niti strankama postupka.

U pojedinim državama, osobito onim koji se temelje na common law sustavu, radi osiguranja sudačke neovisnosti koja u sebi, između ostalog, sadrži i pravo suca da slobodno i neovisno izrazi i javno objavi svoje profesionalno mišljenje, sucima se daje pravo i mogućnost objave, tzv. izdvojenog mišljenja. To se pravo postupno proširilo i na mnoge države izvan common law sustava, osobito na nacionalne ustavne sudove i međunarodne sudove.

Cilj ovoga rada je odrediti pojam, vrste i sadržaj instituta izdvojenog mišljenja kao i njegova osnovna obilježja te kroz prikaz njegova povijesnog razvitka $\mathrm{i}$ analizu komparativne prakse razjasniti teorijske i praktične dvojbe o njegovoj (ne) prihvatljivosti. Slijedom toga prikazati pravno uređenje izdvojenog mišljenja u hrvatskom pravnom sustavu te na temelju analize prakse Ustavnog suda Republike Hrvatske ocijeniti njegovu primjenu i učinke u ustavnosudskim postupcima.

\section{POJAM I VRSTE IZDVOJENOG MIŠLJENJA}

Demokratsko društvo ne stvara trajni, čvrsti i nepromjenjivi sustav vrijednosti, već nastoji izgladiti neslaganja i suprotnosti između različitih, ponekad i nespojivih vrijednosti. Jedna od svrha prava upravo je upravljanje takvim neslaganjima osiguravanjem rješavanja sporova na način kojim se štiti interes stabilnosti odnosno pravne izvjesnosti, ali bez a priori isključivanja različitih opcija odnosno mogućih ishoda. Izvjesnost rješenja spora u sudskom postupku, što nedvojbeno predstavlja vrlo snažnu vrijednost, postiže se metodom većinskog glasovanja i primjenom doktrine res iudicata. ${ }^{1}$ Međutim, zakoni kao opći propisi po svojoj naravi sadrže

1 Usp. Alder, J., Dissents in Courts of Last Resort: Tragic Choices?, Oxford Journal of Legal Studies, v. 20, no. 2, 2000., str. 222. 
određenu razinu neodređenosti što neminovno zahtijeva njihovo tumačenje. Pritom, kako zbog dinamike života i potreba uvažavanja stalnih promjena u društvu pravi smisao zakona ne može do kraja biti određen samim njegovim tekstom, tako i njegova tumačenja ovise o političkom, socijalnom i ekonomskom kontekstu. ${ }^{2}$

$\mathrm{U}$ tom smislu Kelsen navodi kako norma koju treba primijeniti u konkretnom slučaju tvori samo okvir unutar kojeg postoji više mogućnosti primjene, pri čemu je normi sukladan svaki akt koji se drži unutar tog okvira. Tumačenje nekog zakona stoga ne mora neizbježno voditi jednoj jedinoj odluci kao jedinoj ispravnoj nego možda i većem broju odluka, koje su sve jednako vrijedne, iako samo jedna od njih u aktu sudske presude postaje pozitivnim pravom. ${ }^{3}$

$\mathrm{Na}$ tragu takvog razmišljanja Smerdel navodi kako se do istine dolazi kroz suprotstavljanje argumenata i kontradiktornost, jer nijedan pravni propis nije tako jasan i iscrpan da ga se u slučaju kad je potrebno donijeti tešku odluku ne bi moglo tumačiti različito i niti jedna istina nije takva da je ne bi trebalo preispitati. ${ }^{4}$

Slično tomu Alder ističe kako demokratska načela zahtijevaju da se niti jednoj određenoj politici (policy) ili vrijednosti ne daje prednost trajno te tako „vežu ruke" sljedećim generacijama, već se trebaju naći takva rješenja za konkretan slučaj koja će ostaviti otvorenom mogućnost kasnije promjene. Stoga zakon mora pružiti mehanizam za upozoravanje i rješavanje neslaganja bez razarajućih učinaka. Neodređenost zakona sucima daje slobodu, nasuprot ograničenog raspona izbora unutar danog interpretativnog okvira. ${ }^{5}$

Donošenje sudske odluke misaoni je proces u kojem na suce utječu određeni vanjski čimbenici, ali i niz njihovih osobnih svojstava, od intelektualnih sposobnosti, stručnog znanja, praktičnih vještina i životnog iskustva do naravi, predrasuda, interesa i snage. Kombinacija svih tih varijabli rezultira time da čak i suci koji međusobno imaju jednako ili slično obrazovanje i sposobnosti te razmišljaju na isti način, iz iste građe mogu izvući različite zaključke koji su jednako vrijedni.

U samoj biti sudačke neovisnosti pravo je suca da slobodno i neovisno od bilo koga izrazi i javno priopći svoje pravno mišljenje. No kad odlučuje kolektivno sudsko tijelo presuda, ako nije jednoglasna, predstavlja mišljenje većine koja je za nju glasovala. U toj presudi nema mišljenja suca koje se razlikuje od većinskog. Stoga se otvara pitanje što je s njegovim pravom da izrazi i javno iznese svoje pravno mišljenje? Nije li time dovedena u pitanje njegova sudačka neovisnost?

Mnogi pravni sustavi taj problem riješili su tako da su u sudske postupke uveli institut izdvojenog mišljenja. Njegova primjena, međutim, otvorila je niz drugih pitanja kojima se još uvijek bave ne samo pravna praksa već i pravna teorija.

Institutom izdvojenog mišljenja puno se više bavi pravna teorija u državama koji se temelje na common law sustavu u odnosu na države kontinentalnog

2 Antić, T., Vjerodostojno tumačenje zakona, Zbornik Pravnog fakulteta Sveučilišta u Rijeci, v. 36, br. 1, 2015., str. 619.

3 Kelsen, H., Čista teorija prava, Zagreb, Naklada Breza, 2012., str. 75-76.

4 Smerdel, B., O sudskoj slozi i izdvojenim mišljenjima, Informator, br. 5944, 2011., str. 3.

5 Alder, J., op. cit., str. 222-224. 
(civilnog) prava što se može utvrditi već običnim pretraživanjem interneta. Naime, jedan od postojanih elemenata britanske i američke pravne tradicije mogućnost je izražavanja pojedinačnih mišljenja sudaca koji sudjeluju u postupku kao izraz njihove neovisnosti i slobode izražavanja mišljenja. U tom sustavu institut izdvojenog mišljenja bio je kroz povijest više puta osporavan, preispitivan, napušten i ponovo prihvaćen kao sastavni dio procesa donošenja sudskih odluka. ${ }^{6}$

Prema tradicionalnom shvaćanju u tom smislu postoji razlika između kontinentalnog sustava gdje su odluke suda impersonalne (,izlaze“ kao odluke suda u cjelini i iz njih nije vidljivo jesu li donesene jednoglasno ili većinom glasova sudaca niti kako je koji sudac glasovao) i common law sustava u kojem je vidljivo ne samo kako je tko glasovao, već svaki pojedini sudac može javno izraziti svoje drukčije mišljenje. ${ }^{7}$

Ta razlika, međutim, u praksi se pomalo gubi pa je odnos prema izražavanju pojedinačnih pravnih mišljenja i stajališta sudaca u nacionalnim i međunarodnim pravnim sustavima danas vrlo različit i kreće se u rasponu od slobodnog izražavanja seriatim mišljenja ${ }^{8}$ koje se još uvijek prakticira na Vrhovnom sudu Ujedinjenog Kraljevstva do zabrane objave i kriminalizacije kršenja tajnosti različitih razmišljanja unutar suda, primjerice u Belgiji. No u većini demokratskih država sucima se ipak, uz manja ili veća ograničenja, dopušta izražavanje vlastitog mišljenja, drukčijeg od većinskog odnosno onog koje je zauzeo sud. To se mišljenje naziva izdvojenim mišljenjem (lat. votum separatum, engl. separate opinion).

U tom smislu izdvojeno mišljenje u pravnoj teoriji definira se kao mišljenje jednog ili više sudaca koji se ne slažu s odlukom donesenom od strane većine. ${ }^{9}$ U praksi je ono češće vezano uz najviše nacionalne i međunarodne sudove pa se definira i kao oblik pisanog sudačkog mišljenja u radu jednog broja najviših nacionalnih i međunarodnih sudova kojim se jedan ili više sudaca ne slaže s odlukom većine ili razlozima kojima se obrazlaže. ${ }^{10}$ Institut izdvojenog mišljenja može se odrediti i kao demokratski mehanizam koji odražava razmišljanje onih koji se razilaze s većinskim glasom odnosno mišljenjem o nekom pitanju. ${ }^{11}$

Definicija je na prvi pogled jednostavna i jasna. Međutim, pojam izdvojenog mišljenja nije jednoznačan, jer u sebi zapravo sadrži dvije razine neslaganja $\mathrm{s}$ većinskim mišljenjem:

6 Vitale, D., The Value of Dissent in Constitutional adjudication: a context-specific analysis, Review of Constitutional Studies, v. 19, no. 1 (2014), str. 7, <www.thefreelibrary.com/...>, 3. siječnja 2016.

7 Krbek, I., Ustavno sudovanje, Zagreb, Jugoslavenska akademija znanosti i umjetnosti, 1960., str. 86 .

8 Vidi infra, bilj. 22.

9 Black's Law Dictionary, ed. Garner, B. A., St. Paul, USA, Thomson,West, 2004., str. 1125.

10 Pravni leksikon, gl. ur. Pezo, V., Zagreb, Leksikografski zavod, 2007., str. 487.

11 Altan, A., The role of Dissenting and Concurring Opinions in Turkish Practice - Report for the Black Sea Regional Conference on the Importance of Dissenting and Concurring Opinions in the Development of Judicial Review (Batumi, Georgia, 2010), CDL-JU(2010)017, Strasbourg, Council of Europe, European Commission for Democracy through Law (Venice Commission), 2010., str. 2, <www.venice.coe.int >, 15. prosinca 2015. 
1. kad sudac prihvaća odluku većine o meritumu, ali nije suglasan s obrazloženjem odnosno razlozima na kojima je utemeljena i

2. kad se sudac protivi odluci o meritumu i glasuje protiv njezina usvajanja; po naravi stvari to znači da se protivi i njezinom obrazloženju. ${ }^{12}$

U prvom slučaju riječ je o „blažem“ obliku neslaganja s mišljenjem većine, jer se sudac slaže s odlukom o meritumu, dakle s izrekom, ali se u određenoj mjeri ne slaže s njezinim obrazloženjem. U hrvatskoj pravnoj literaturi za tu vrstu izdvojenog mišljenja obično se koristi izraz „potvrđujuće izdvojeno mišljenje“13, iako bi bolji izraz bio „podudarno izdvojeno mišljenje“"14 koji, osim što više odgovara međunarodno opće prihvaćenom engleskom izrazu concurring opinion ${ }^{15}$, bolje označava sadržaj i značenje tog instituta. U takvom izdvojenom mišljenju sudac iznosi svoje posebne razloge za donošenje sudske odluke. Pritom sudac može izraziti neslaganje s pojedinim dijelovima obrazloženja, može jače istaknuti važnost pojedinih iznesenih razloga, a može iznositi i potpuno nove razloge u prilog donesene odluke kojih u njezinu obrazloženju nema odnosno dopuniti njezino obrazloženje. ${ }^{16}$

U drugom slučaju sudac se ne slaže s većinskim mišljenjem (engl. majority opinion, main opinion) i svoje glasovanje protiv odluke obrazlaže u posebnom pisanom mišljenju u kojem navodi razloge protiv donošenja odluke u sadržaju kako je to utvrdilo sudsko tijelo (engl. dissenting opinion ili skraćeno dissent). ${ }^{17}$ Riječ je dakle o obrazloženju suca o razlozima glasovanja suprotno većini. ${ }^{18}$ Naravno da su

12 Krbek, I., op. cit., str. 86, bilj. 157; Mavčić, A. M., Importance of the Dissenting and Concurring Opinions (Separate Opinions) in the Development of the Constitutional and Judicial Review with a Special Reference to the Slovenian Practice - Report for the Black Sea Regional Conference on the Importance of Dissenting and Concurring Opinions in the Development of Judicial Review (Batumi, Georgia, 2010), CDL-JU(2010)016, Strasbourg, Council of Europe, European Commission for Democracy through Law (Venice Commission), 2010., str. 2, <www.venice.coe.int>, 15. prosinca 2015.; Smerdel, B. i Sokol, S., Ustavno pravo, Zagreb, Narodne novine, 2009., str. 187; Smerdel, B., Ustavno uređenje europske Hrvatske, Zagreb, Narodne novine, 2013., str. 435.

13 Primjerice Uzelac, A., Lustracija, diskvalifikacija, čistka - O procesima i ustavnopravnim problemima izbora sudaca u „prijelaznom razdoblju“, Iudex, v. 3, br. 1, 1995., str. 421. i Crnić, J., Komentar Ustavnog zakona o Ustavnom sudu Republike Hrvatske, Zagreb, Narodne novine, 2002., str. 60.

14 Usp. Perić, B, Izdvojeno sudijsko mišljenje u krivičnom postupku - argumenti za novi pristup, Pravni život, br. 10, 2009., <www.pravosudje.ba/vstv/...>, 17. prosinca 2015.

15 Concurring opinion označava izdvojeno pisano mišljenje suca u kojem on svoj glas za donesenu odluku suda obrazlaže razlozima koji se razlikuju od onih izraženih u obrazloženju odluke. Black's, op. cit., str. 309. i 1125.

16 S obzirom na to Crnić unutar te kategorije razlikuje „izdvojeno konkurirajuće mišljenje“ (kojim sudac upućuje na druge razloge iz kojih je glasovao za odluku u odnosu na razloge iz obrazloženja) i ,izdvojeno odobravajuće (potvrđujuće) mišljenje“ (kojim sudac dopunjuje razloge odluke). Crnić, J., op. cit., str. 60.

17 Dissenting opinion označava mišljenje jednog ili više sudaca koji se ne slažu s odlukom koju je donijela većina sudaca. Black's, op. cit., str. 506 i 1125.

18 Crnić upozorava kako pojam „,suprotni glas“ nije sinonim za pojam ,izdvojeno mišljenje“, jer ne postoji obveza suca na pisano obrazloženje suprotnoga glasa. Crnić, J., op. cit., str. 58. O tomu opširnije vidi infra u poglavljima 4. i 6. 
tada ti razlozi suprotni odlučujućim razlozima za donošenje odluke navedenim u njezinu obrazloženju.

U common law državama postoji i treća, uvjetno rečeno najblaža vrsta neslaganja pojedinog suca koja, međutim, ne rezultira njegovim pisanim izdvojenim mišljenjem. Riječ je o tzv. dubitante opasci koju stavlja sudac kada nije uvjeren u ispravnost odluke, ali ne u tolikoj mjeri da bi izdvojio svoje mišljenje. ${ }^{19}$

Pojam izdvojenog mišljenja u hrvatskom pravnom sustavu ima dvojako značenje:

- u širem smislu obuhvaća potvrđujuće odnosno podudarno izdvojeno mišljenje i suprotno izdvojeno mišljenje (u značenju engleskog izraza separate opinion),

- u užem smislu ono označava samo suprotno izdvojeno mišljenje (u značenju engleskog izraza dissenting opinion).

Sustavi u kojima je sucima dopušteno izjavljivanje izdvojenog mišljenja razlikuju se s obzirom na pravila njihovog objavljivanja u javnosti odnosno dostupnosti subjektima izvan suda. U tom smislu razlikuju se dva osnovna tipa sustava:

1. sustavi u kojima se izdvojeno mišljenje javno objavljuje zajedno s predmetnom sudskom odlukom i

2. sustavi u kojima se sudskoj odluci pridodaje pisano izdvojeno mišljenje samo uz primjerke koji se dostavljaju strankama postupka.

\section{POVIJESNO-KOMPARATIVNI ASPEKT}

Načelo tajnosti osobnog promišljanja i pojedinačnoga glasovanja sudaca pri kolektivnom odlučivanju utemeljeno je prije svega na povijesnim razlozima. Tradicionalno, uloga sudaca bila je očitovati volju kralja, a budući da kralj može imati samo jednu volju, sudska odluka treba biti jednoglasna ili barem tako mora izgledati.

No od 17. stoljeća nadalje u sudovima common law sustava postupno se počinje preferirati većinsko odlučivanje. U znanstvenoj literaturi kao primjer jednog

19 Opaska dubitante (lat., u značenju: dvojbeno, u sumnji) obično se upisuje u prijedlog odluke uz ime suca označavajući da on sumnja u predloženo pravno stajalište odnosno mišljenje, ali nije uvjeren ni da je ono pogrešno. Black's, op. cit., str. 537. Jedan od poznatijih primjera predmet je Feldman v. Allegheny Airlines Inc. (spor radi naknade štete nastale smrću u zrakoplovnoj nesreći) koji se vodio pred američkim Saveznim žalbenim sudom za drugi sudbeni kotar (United States Court of Appeals for the Second Circuit), u kojem je istaknuti sudac Friendly kao član tročlanoga sudskog vijeća, u presudi izrijekom naveo kako ozbiljno sumnja u ispravnost donesene odluke, ali ipak glasuje sukladno većini, jer se ta sumnja temelji samo na njegovoj intuiciji i ne može dokazati njezinu opravdanost. Feldman $v$. Allegheny Airlines Inc., 1975., toč. 34., <http://openjurist.org/524/f2d/384/feldman-vallegheny-airlines-inc >, 28. siječnja 2016. Sudac Henry J. Friendly bio je sudac Saveznog žalbenog suda za drugi sudbeni kotar od 1959. do 1986. i njegov predsjednik od 1971. do 1973. 
od najranijih predmeta u kojem je izričito priznata neizbježnost neslaganja sudaca često se navodi predmet Grindley v. Barker iz 1798. godine, koji se vodio pred tadašnjim engleskim Kraljevskim sudom (Court of King's Bench) u kojem je sud izrazio stajalište da se odluke koje se ne tiču čisto privatnih odnosa stranaka, već se odnose na pitanja opće naravi odnosno koja su od javnog interesa, ako okolnosti u konkretnom slučaju ne nalažu drukčije, donose većinom glasova. ${ }^{20}$ Pritom odluka koju je donijela većina sudaca čini odluku suda u cjelini, bez obzira na manjinu sudaca koji se s njom nisu složili, po načelu ubi major pars, ibi totum (gdje je veći dio, ondje je i cjelina). ${ }^{21}$

Klasično shvaćanje sudačke funkcije kao „potrage za pravom“ koje treba primijeniti u konkretnom slučaju dovelo je do nastanka prakse u postupanju suda prema kojoj suci koji čine kolektivno sudsko tijelo, redom pojedinačno iznose svoja vlastita „otkrića“ odnosno razloge za donošenje odluke (tzv. seriatim mišljenje, engl. seriatim opinion). ${ }^{22}$ Pritom ne postoji jedno „mišljenje suda“ već se objavljuju sva pojedinačna mišljenja. Sustav ima tu prednost da sudski postupak rezultira nijansiranim $\mathrm{i}$ istančanim pravnim razmišljanjima i stajalištima, ali s druge strane ne postoji jedno jasno izraženo stajalište, pa stoga nije jednostavno odrediti što je uopće sud odlučio. Ipak, smatra se da takvo postupanje odražava i jača tradiciju sudačke neovisnosti i to ne samo od vanjskih utjecaja već i sudaca međusobno pa se ista praksa u nekim državama djelomično i u različitim oblicima održala i do danas (uglavnom u državama Commonwealtha, primjerice u Novom Zelandu, Australiji, Južnoj Africi i Indiji). ${ }^{23}$

Može se reći da institut izdvojenog mišljenja, s obzirom na svoju pravnu narav i sadržaj, proizlazi upravo iz te prakse.

Povijesnom razvoju instituta izdvojenog mišljenja osobito je pridonijela praksa Vrhovnog suda SAD-a čiji utjecaj oduvijek daleko prelazi granice države, a čija moć proizlazi iz njegovih ovlasti i položaja koje zauzima među visokim državnim vlastima o čemu je pisao još Tocqeville, navodeći kako je riječ o sudu koji se: „... nalazi iznad svakoga poznatog suda i prema naravi svojih prava i prema vrsti ljudi koji popadaju pod njegovu nadležnost" te čija su: ,... ovlaštenja gotovo u potpunosti politička, premda mu je ustrojstvo u potpunosti pravosudno". ${ }^{24}$ Pritom se često ističe kako glavni temelj njegova političkog legitimiteta leži u njegovoj

20 Alder, J., op. cit., str. 233. Vidi također Lynch, A., Is Judicial Dissent Constitutionally Protected, Macquarie Law Journal, v. 4, 2004., str. 83, bilj. 10, <www.mq.edu.au/..>, 16. siječnja 2016.

21 Cameron, M. Ian, Majority Rule; the Development of General Principle in Cases on Chartered Corporations, Melbourne University Law Review, 6, v. 15, no. 1, 1985., str. 122. <www.austlii.edu.au/au/journalsMelbULawRw/1985/6.html>, 26. siječnja 2016.

22 Seriatim mišljenja (lat. seriatim - u nizu) označava niz pojedinačnih mišljenja sudaca članova kolegijalnog sudskog tijela, koja se razlikuju od mišljenja tog tijela odnosno suda kao cjeline. Black's, op. cit., str. 1125 i 1398.

23 Friedman, B. i dr., Divide and Concur: Separate opinions and Legal Change, str. 107, <www. law.northwestern.edu/...>, 2. veljače 2016.

24 Tocqueville, A. de, O demokraciji u Americi, Zagreb, Informator, 1995., str. 67. 
povezanosti s idealom vladavine prava. ${ }^{25}$

Jedno od najpoznatijih izdvojenih mišljenja u povijesti američkoga Vrhovnog suda izdvojeno je mišljenje suca Johna M. Harlana ${ }^{26}$ u predmetu Plessy v. Ferguson iz 1896. Riječ je bila o osudi osobe miješane rase (7/8 bijelac, što je po zakonu Savezne države Louisiane značilo da spada u afro-američku grupu stanovnika) koja je putovala željeznicom u prostoru namijenjenom za bijelce, a ne u prostoru za „obojene“ putnike. Vrhovni sud je većinom glasova (7:1) presudio da zakon kojim je propisana obveza odvajanja putnika različitih rasa u zasebne prostore nije protivan Ustavu (13. i 14. amandman) dok god su ti prostori jednake kvalitete. Time je Vrhovni sud kao pravno stajalište prihvatio ideju o ,jednakosti u odvojenosti““ (separate but equal). U izdvojenom mišljenju sudac Harlan izrazio je stajalište da uređenje građanskih prava na temelju pripadnosti rasi u pojedinim saveznim državama nije u suglasnosti s jamstvima saveznog Ustava koji je ,slijep na boje“ („Our Constitution is color-blind“). ${ }^{27}$

Krbek ocjenjuje da je u SAD-u, s obzirom na ustavno sudovanje, tako postavljen sustav bio izuzetno uspješan, jer je kod sudaca podigao ambiciju i osjećaj odgovornosti, ojačao kvalitetu presuda, spriječio stagniranje judikature i omogućio progres te razvio umjesnu kritiku presude. ${ }^{28}$

Praksa izjavljivanja izdvojenih mišljenja na Vrhovnom sudu SAD-a bila je prekinuta u razdoblju predsjedanja njegova najznačajnijeg i najutjecajnijeg predsjednika, suca Johna Marshalla, ${ }^{29}$ kada je prihvaćeno njegovo stajalište da će jedno jedinstveno ,mišljenje suda“, iako stvarno predstavlja mišljenje većine, a ne svih, povećati autoritet suda. Bio je to odgovor na kritike da izdvojena mišljenja unose nesigurnost u pravni sustav i potkopavaju autoritet suda. U postupanju suda uvedena je praksa održavanja sastanaka sudaca na kojima su oni razmjenjivali svoje argumente i razmišljanja, utvrđivali međusobne razlike i nalazili zajedničke osnove, što je olakšavalo i pridonosilo donošenju jedinstvene odluke suda. ${ }^{30}$

25 Stack, K. M., The practice of Dissent in the Supreme Court, The Yale Law Journal, vol. 105, 1996., str. 2235, <htpps://discoverarchive.vanderbilt.edu/..>>, 15. veljače 2016. Istodobno, međutim, napominje kako se u praksi Vrhovnog suda njegov politički legitimitet i ideal vladavine prava baš uvijek ne poklapaju.

26 Sudac John Marshall Harlan bio je sudac Vrhovnog suda SAD-a (Associate Justice of the United States Supreme Court) od 1877. do 1911. godine.

27 Vitale, D., op. cit., str. 3. Pritom je zanimljivo da su sudac Harlan i njegova obitelj prethodno imali svoje robove i za vrijeme Američkoga građanskog rata (1861. - 1865.) branili pravo robovlasništva. Inače, presuda u ovom predmetu bila je korištena kao presedan sve do presude Vrhovnog suda u predmetu Brown v. Board of Education iz 1954. godine (vidi infra u poglavlju 4.).

$<$ http://americanhistory.about.com/od/supremecourtcases/p/plessy.htm>, 30. prosinca 2015.

28 Krbek, I., op. cit., str. 86.

29 Sudac John Marshall bio je predsjednik Vrhovnog suda SAD-a (Chief Justice of the United States) od 1801. do 1835. godine i osobito je poznat po predmetu Marbury v. Madison iz 1803., u kojem je izrazio tumačenje da u slučaju kad je zakon koji treba primijeniti na spor protivan Ustavu, spor mora biti riješen po Ustavu, a ne po običnom zakonu, čime je u SAD-u bilo utemeljeno pravo sudova na nadzor ustavnosti zakona. Marbury v. Madison, str. 15, $<$ http://caselaw.lp.findlaw.com... >, 27. prosinca 2015.

30 Ledebur, E. L., Plurality Rule: Concurring Opinions and a Divided Supreme Court, Pen State Law Review, vol. 113, no. 3, 2009., str. 902, <http://penstatelawreview.org/articles/..>>, 
Takvu praksu uveo je i sudac Bora Laskin u vrijeme svog predsjedanja Vrhovnim sudom Kanade. ${ }^{31}$ Zajedničkim raspravama sudaca prije odlučivanja, približavanjem različitih pojedinačnih stavova, pa čak i svojevrsnim međusobnim pregovaranjem i lobiranjem sudaca (judicial lobbying), nastojale su se izbjeći situacije u kojima suci pojedinačno pišu svoja obrazloženja izolirani jedni od drugih, vjerno i savjesno slijedeći presedane na temelju doktrine stare decisis ${ }^{32}$. Nakon zajedničke rasprave suci su se mogli opredijeliti hoće li se prikloniti većinskom mišljenju, iznijeti podudarno mišljenje (concurring opinion) ili napisati izdvojeno mišljenje (dissenting opinion). ${ }^{33}$

Sličnih pokušaja bilo je i na Visokom sudu Australije, gdje su pojedini njegovi predsjednici (Dixon, Barwick, Mason, Gleeson) također nastojali osigurati veći konsenzus u odlučivanju sudskih tijela i smanjiti broj odluka s pojedinačnim izdvojenim mišljenjima. ${ }^{34}$

Ipak, u common law sustavima pravo sudaca na izjavljivanje izdvojenog mišljenja uz veća ili manja ograničenja ostalo je inherentno sudačkoj dužnosti, prije svega kao izraz slobode mišljenja i njihove sudačke neovisnosti.

Iako je opće mišljenje da je pravo na izjavljivanje izdvojenog mišljenja povijesno gledajući posebnost common law sustava, dok je za tradiciju europskoga kontinentalnog prava karakteristično načelo tajnosti promišljanja odnosno odlučivanja, to nije u potpunosti točno, jer je primjera izdvajanja mišljenja bilo u pravnoj povijesti i na području kontinentalne Europe. Tako pravo na iskazivanje neslaganja u Španjolskoj datira još iz 15. stoljeća kada su uredbom iz Medine dopuštena izdvojena mišljenja (nazvana voto reservado) koja su se upisivala u nejavnu knjigu i nisu se objavljivala. Takvo postupanje očuvalo se i zakonima o građanskom i kaznenom postupku iz 1881. i 1882. i ostalo je na snazi sve do 1985. kad je praksa izdvajanja mišljenja proširena na čitav pravni sustav. U pojedinim talijanskim područjima prije ujedinjenja države također je postojala mogućnost izdvajanja mišljenja, primjerice u tadašnjim kraljevstvima Napulj, Este i Toskana. Na području današnje Njemačke izdvojena mišljenja bila su objavljivana sve do sredine 19. stoljeća u državi Baden, a u državi Württemberg sve do Drugog svjetskog rata glasovanje je bilo javno. ${ }^{35}$

2. veljače 2016. Vidi i Friedman, B. i dr., op. cit., str. 112-113. S druge strane, tadašnji predsjednik SAD-a Thomas Jefferson ocijenio je Marshallow model kao ,prikladan za lijene, stidljive i nestručne“. Vitale, D., op. cit., str. 6.

31 Sudac Bora Laskin bio je predsjednik Vrhovnog suda Kanade (Chief Justice of Canada) od 1973. do 1984. godine.

32 Stare decisis jedna je od temeljnih doktrina common law sustava prema kojoj sud mora slijediti raniju sudsku odluku kada se u suđenju pojavi isto pitanje. Pritom postoje dvije komponente: 1. držati se odluke višeg suda i vlastite ranije odluke, 2. ne mijenjati svoje ranije zauzeto stajalište, osim kod postojanja osobito jakih razloga. Naziv proizlazi iz latinske izreke Stare decisis et non quieta movere (ostati kod odluke i ono što je mirno ne dirati). Black's, op. cit., str. 1443.

33 Morton, L. F., Law, Politics and the Judicial Process in Canada, Calgary (Canada), University of Calgary Press, 2002., str. 534.

34 Lynch, A., op. cit., str. 86.

35 Kelemen, K., Dissenting Opinions in Constitutional Courts, German Law Journal, vol. 14, no. 8, 2013., str. 1347, <www.diva-portalog.org/...>, 15. prosinca 2015. 
U novije vrijeme izgubila se stroga razlika između država common law sustava i država europskoga kontinentalnog sustava. U mnogim državama kontinentalnog prava dopušteno je objavljivanje izdvojenih mišljenja, dok je u nekim državama common law sustava ono ograničeno ili čak zabranjeno pa danas između sudova u državama oba sustava postoje međusobne sličnosti i razlike.

S obzirom na taj kriterij, Friedman i dr. razlikuju tri vrste sudova: a) sudove u kojima svaki sudac piše svoje mišljenje neovisno o drugim sucima, a sudska odluka predstavlja kasnije više ili manje usuglašena pojedinačna mišljenja uz mogućnost izdvajanja mišljenja (seriatim courts), b) sudove u kojima izdvajanje mišljenja apsolutno nije dopušteno (suppressed courts) i c) sudove koji se načelno drže zahtjeva jednoglasnosti, ali pokazuju određenu toleranciju prema izdvajanju mišljenja (hybrid courts), pa iako sud donosi samo jednu odluku, pojedini sudac može svoje drukčije mišljenje objaviti u posebnoj publikaciji (primjerice suci talijanskog Ustavnog suda u znanstvenoj publikaciji Giusprudenza Costitutionale, a suci Europskog suda pravde u publikaciji Advocate general). ${ }^{36}$

Studija o praksi objavljivanja izdvojenih mišljenja na najvišim sudovima u državama Europske unije (u daljnjem tekstu: EU) iz 2012. godine pokazala je da od tadašnjih 27 država članica, samo sedam ne dopušta objavu izdvojenih mišljenja, dok je u preostalih 20 država to dopušteno, bilo u svim postupcima ili samo u ustavnopravnim pitanjima. Uočen je rastući trend dopuštanja objavljivanja izdvojenih mišljenja ustavnih sudaca, osobito u državama Istočne Europe. Jednako tako, utvrđeno je da je objavljivanje izdvojenih mišljenja općenito dopušteno na međunarodnim i regionalnim nadnacionalnim sudovima, s izuzetkom Suda Europske unije (Court of Justice of the European Union, CJEU). ${ }^{37}$

1. Unutar država članica EU-a izdvojena mišljenja općenito nisu dopuštena u Belgiji, Francuskoj, Italiji, Luksemburgu, Malti, Nizozemskoj i Austriji.

Belgijski sudbeni sustav počiva na načelu tajnosti sudačkog odlučivanja što se istodobno tumači i kao zabrana objavljivanja osobnih sudačkih mišljenja. Štoviše, prema stajalištu Vrhovnog suda (Cour de cassation/Hof van Cassatie) kršenje ovog načela, u što spada i objavljivanje izdvojenog mišljenja, kažnjivo je na temelju kaznenog zakona. Iako prisega koju polažu suci pri stupanju na dužnost izričito ne spominje čuvanje tajnosti o odlučivanju, svi sudovi, uključujući i Ustavni sud (Cour Constitutionnelle), poštuju pravilo o neobjavljivanju izdvojenih mišljenja.

U francuskom sudbenom sustavu također vrijedi načelo tajnosti o odlučivanju koje se izričito tumači kao zabrana objavljivanja izdvojenih mišljenja. Francuski državni savjet (Conseil d'État, najviše upravno sudište) zabranjuje čak i javno

36 Friedman, B. i dr., op. cit., str. 107-110.

37 Raffaelli, R., Dissenting opinions in the Supreme Courts of the Member States, Brussels, European Parliament, Directorate-General for Internal Policies - Policy Department, 2012., str. 7, <www.europarl.europa.eu/studies>, 23. prosinca 2015. Riječ je o studiji izrađenoj za potrebe Odbora za pravna pitanja Europskog parlamenta s ciljem istraživanja prakse ustavnih i vrhovnih sudova država članica EU-a i nadnacionalnih institucija te uočavanja glavnih teorijskih argumenata u prilog i protiv dopuštenja objave izdvojenih mišljenja, posebice u odnosu na moguću primjenu na Sudu Europske unije. 
objavu da je odluka donesena jednoglasno, jer bi se tako otkrio individualni glas svakoga pojedinog suca. Osim što je propisana zakonom, tajnost o odlučivanju dio je i sudačke prisege, i to ne samo sudaca redovnih sudova, već i članova Ustavnog vijeća (Conseil Constitutionell, najviše ustavnosudsko tijelo).

Načelo tajnosti o odlučivanju primjenjuje se i u Italiji i to na redovnim sudovima kao i na Ustavnom sudu (Corte costituzionale della Repubblica Italiana), a njegova povreda je kažnjiva. Ipak, od 1988. godine sucima je dopušteno izdvojiti mišljenje koje se na njihov zahtjev posebno bilježi i čuva u zatvorenoj koverti.

Tajnost odlučivanja i glasovanja važi i za sve sudove, uključujući i ustavne sudove, u Luksemburgu i na Malti. Isto načelo primjenjuje se $\mathrm{i}$ na sve sudove $\mathrm{u}$ Nizozemskoj (koja inače nema ustavni sud niti slično tijelo).

Sudovi u Austriji također se dosljedno drže načela tajnosti odlučivanja i glasovanja sudaca, što obuhvaća i suce Ustavnog suda (Verfassungsgerichtshof, $V f G H)$. Suci mogu izdvojiti svoje mišljenje što se posebno bilježi, ali se to mišljenje ne objavljuje i dostupno je samo određenom krugu osoba. ${ }^{38}$

2. U državama članicama EU-a u kojima su dopuštena izdvojena mišljenja, taj institut nije u svima uređen na jednak način, a različita je i praksa sudova. U tom smislu postoji osnovna podjela na dvije grupe država: one u kojima je objava izdvojenog mišljenja dopuštena sucima svih sudova i one u kojima je to dopušteno samo ustavnim sucima.

U Bugarskoj je dopuštena objava izdvojenih mišljenja na svim sudovima. $\mathrm{Na}$ Ustavnom sudu (Конституционен съд на Република България), međutim, izdvojena mišljenja nisu dopuštena u predmetima u kojima se odlučuje tajnim glasovanjem (imunitet suca ili njegova nesposobnost za obavljanje dužnosti, odgovornost predsjednika Republike). Izdvojena mišljenja ustavnih sudaca objavljuju se zajedno s odlukom Ustavnog suda u državnom službenom glasilu.

Na Cipru je ustavnosudska kontrola u nadležnosti Vrhovnog suda (Kú

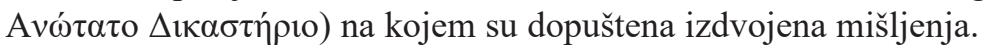

Češka ne dopušta objavu izdvojenih mišljenja sudaca redovnih sudova, već samo sudaca Ustavnog suda (Ústavní soud České republiky). Međutim, izdvojeno mišljenje se objavljuje samo u vlastitom izvješću suda, dok se u državnom službenom glasilu (Sbírka zákonů České republiky) na kraju odluke suda samo stavlja napomena o njegovom postojanju.

Danska nema poseban ustavni sud, već kontrolu ustavnosti propisa obavljaju svi sudovi, uz krajnju nadležnost Vrhovnog suda (Højesteret). Izdvojena mišljenja objavljuju se kao dio sudske odluke s imenom suca koji ga je izjavio.

U Estoniji su izdvojena mišljenja dopuštena gotovo na svim sudovima. Objava izdvojenih mišljenja izričito je dopuštena u postupcima ustavnosudske kontrole koju provodi poseban odsjek Vrhovnog suda (Riigikohus), a jednako tako na sudovima u civilnim i upravnim sudskim postupcima. Međutim, u kaznenim postupcima izdvojena mišljenja se samo bilježe u spisu, ali se ne objavljuju. 
Finska nema poseban ustavni sud već ustavnosudsku kontrolu provode svi sudovi. Sucima je dopušteno objaviti izdvojeno mišljenje u redovitim postupcima kao i u postupcima kontrole ustavnosti.

U Grčkoj ustavnosudsku kontrolu također provode svi sudovi, a izdvojena mišljenja su dopuštena u svim vrstama postupka. Njihova objava nije samo dopuštena već je i obvezna, ali se pritom anonimiziraju - objavljuje se samo broj protivnih glasova i njihovo obrazloženje, ali bez imena sudaca.

Irski pravni sustav vrlo je specifičan po pitanju izdvojenih mišljenja. U većini ustavnosudskih postupaka ona su zabranjena već samim Ustavom. Sucima redovnih sudova dopuštena su izdvojena mišljenja. Jednako tako dopuštena su i sucima Vrhovnog suda (Cúirt Uachtarach na hÉireann), ali samo kad odlučuju o predmetima iz redovite nadležnosti. Međutim, kad odlučuju u predmetima ustavnosudske kontrole, sud donosi jedinstvenu odluku bez izdvojenih mišljenja, bilo potvrđujućih (podudarnih) ili suprotnih, niti se njihovo postojanje na bilo koji način obznanjuje.

U Latviji sucima redovnih sudova nije dopušteno objavljivati izdvojena mišljenja. Ta je mogućnost, međutim dopuštena sucima Ustavnog suda (Latvijas Republikas Satversmes tiesa). Pritom se izdvojena mišljenja nakon donošenja i objave odluke suda najprije dostavljaju svim sucima koji su sudjelovali u odlučivanju i objavljuju tek naknadno i odvojeno.

Litva ima sustav u kojem je objavljivanje izdvojenih mišljenja dopušteno sucima redovnih sudova kao i sucima Ustavnog suda (Lietuvos Respublikos Konstitucinis Teismas). U ustavnosudskim postupcima izdvojena mišljenja se prilažu uz odluku u spisu i objavljuju na mrežnoj stranici suda, a stranke u postupku i mediji samo se se obavještavaju o njihovom postojanju.

U Mađarskoj se izdvojena mišljenja sudaca Ustavnog suda (Magyarország Alkotmánybirósága) objavljuju zajedno s odlukom suda. Na redovnim sudovima izdvojena mišljenja se ne objavljuju, već se zatvaraju u posebnu kuvertu i dostupna su samo višim sudovima u žalbenom postupku.

$\mathrm{Na}$ njemačkom Saveznom ustavnom sudu (Bundesverfassungsgericht, $B \operatorname{VerfG}$ ) izdvojena mišljenja (Sondervotum) i njihova objava dopuštena su izričitom zakonskom normom. Riječ je o iznimci u sustavu, jer na redovnim sudovima objava izdvojenih mišljenja nije dopuštena.

Poljska ima sustav u kojem je objavljivanje izdvojenih mišljenja dopušteno sucima redovnih sudova kao i sucima Ustavnog suda (Trybunat Konstytucyjny). Izdvojeno mišljenje može biti potvrđujuće (podudarno s izrekom odluke, a različito samo u odnosu na obrazloženje) ili suprotno većinskoj odluci.

U Portugalu suci Ustavnog suda (Tribunal Constitucional) mogu pisano obrazložiti svoj glas protiv većinskog mišljenja (voto vencido, doslovce prevedeno: poraženi glas). Ako je riječ o sucu izvjestitelju, predsjednik suda imenuje nekog od drugih sudaca za izradu konačne (većinske) odluke suda. Izdvojena mišljenja dopuštena su i na redovnim sudovima.

Rumunjska također ima sustav u kojem su izdvojena mišljenja dopuštena na redovnim sudovima kao i na Ustavnom sudu (Curtea Constituţională a României). 
Izdvojena mišljenja ustavnih sudaca objavljuju se u službenom glasilu zajedno s odlukom suda.

Slovenski Ustavni sud (Ustavno sodišče Republike Slovenije, US RS) također dopušta izdvojena mišljenja koja se dostavljaju strankama postupka zajedno s odlukom. Ona se, međutim, objavljuju samo na mrežnoj stranici suda, ali ne i u državnom službenom glasilu i to zbog banalnog razloga: troškova objave koje mora podmiriti sud. Na redovnim sudovima objava izdvojenog mišljenja nije dopuštena.

U Slovačkoj suci Ustavnog suda (Ústavný súd Slovenskej republiky) mogu izdvojiti svoje mišljenje i tražiti da se ono ukratko zabilježi u zapisniku o glasovanju, a u cijelosti objavi. Izdvajanje mišljenja dopušteno je i na redovnim sudovima, ali ta mogućnost u praksi još nikad nije korištena.

Španjolski Ustav iz 1978. izričito dopušta izdvojena mišljenja u postupcima pred Ustavnim sudom (Tribunal Constitucional de España). Od 1985. na temelju Organskog zakona o sudbenoj vlasti (Ley Orgánica del Poder Judicial) mogućnost izjavljivanja pojedinačnih izdvojenih mišljenja (votos particulares) proširena je i na sve redovne sudove.

U Švedskoj nadležnost za obavljanje ustavnosudske kontrole imaju svi sudovi na čelu s Vrhovnim sudom (Högsta domstolen, HD). Mogućnost izdvajanja mišljenja sudaca dopuštena je u redovnim sudskim predmetima kao i u predmetima ustavne kontrole.

Sudovi u Ujedinjenom Kraljevstvu tradicionalno donose odluke seriatim. Svi suci pojedinačno predaju svoja osobna mišljenja, a nakon toga odluka se donosi većinom. Takav način odlučivanja potiče od sustava u kojem najvišu sudsku instancu čini Odbor za žalbe Doma lordova (Appellate Committee of the House of Lords). Nakon donošenja Zakona o ljudskim pravima (Human Rights Act) iz 1998. godine s ciljem inkorporiranja prava sadržanih u Europskoj konvenciji o ljudskim pravima u domaće pravo, uvedena je difuzna kontrola temeljena na Konvenciji. Godine 2009. Odbor za žalbe zamijenjen je formalno neovisnim Vrhovnim sudom (Supreme Court) koji je zadržao tradiciju seriatim odlučivanja, uključujući i postupke koji se odnose na Zakon o ljudskim pravima, za koje se može reći da je riječ o predmetima ustavnosudske kontrole.

Dakle, unutar 20 država članica EU-a s praksom izdvojenih mišljenja, najviše (13) je onih koje dopuštaju njihovu objavu u svim vrstama postupka, u šest država dopuštena je objava samo u postupcima ustavnosudske kontrole, a u jednoj samo u redovnim sudskim postupcima. ${ }^{39}$

No osim u navedenim državama EU-a, objava izdvojenih mišljenja dopuštena je i u mnogim drugim državama širom svijeta, primjerice u Bosni i Hercegovini, Crnoj Gori, Makedoniji, Moldaviji, Norveškoj, Srbiji, Armeniji, Azerbajdžanu, Gruziji, Turskoj, Ukrajini, Kanadi, Argentini i Čileu. ${ }^{40}$

39 Ibid., str. 20-29.

40 Mavčić, A., op. cit., str. 3. 


\section{PRAVNO-TEORIJSKA PITANJA}

Teorijske rasprave o institutu izdvojenog mišljenja oduvijek su polazile od njegova utjecaja na legitimitet sudova. Pitanje demokratskog legitimiteta ključno je za točnu i potpunu analizu fenomena sudačkog izdvojenog mišljenja.

Prema Kelemen kad je riječ o raspravi o pitanju legitimiteta glavnu ulogu u tome imaju dva osnovna načela koja se oba bezuvjetno odnose i na pitanje izdvojenih mišljenja: sudačka neovisnost i transparentnost odlučivanja. Ta dva načela moraju se smatrati temeljem demokracije, ali njih nije lako dovesti u ravnotežu. ${ }^{41}$

S tog aspekta koncepcija dopuštenosti izdvojenih mišljenja sudaca i njihove javne objave u pravnoj teoriji otvara mnoga pitanja na koja teoretičari daju različite odgovore i zastupaju različita stajališta o (ne)poželjnosti takve prakse.

Prvo pitanje od kojeg polazi rasprava o institutu izdvojenog mišljenja pitanje je razloga neslaganja odnosno kada i zašto između sudaca dolazi do razlike u mišljenjima.

Alder smatra kako postoji niz nespojivih vrijednosti i interesa koji svaki za sebe zaslužuju poštovanje, ali su u stalnoj međusobnoj borbi odnosno suparništvu. Ljudska priroda nije dosljedna i postojana, jer u svakom čovjeku postoje porivi koji se stalno međusobno natječu, ne samo u odnosu s okolinom već i unutar njega samog (primjerice potrebe za samoćom i za društvom, potrebe za promjenom i za stabilnošću i dr.). S obzirom na to, u sudskim postupcima razlikuju se četiri osnovne vrste nepomirljivih razilaženja koja obično dolaze do izražaja na žalbenim odnosno višim sudovima:

1. Prva vrsta razilaženja odnosi se na neslaganje o bitnim etičkim ili političkim vrijednostima. Ono osobito nastaje u postupcima vezanim uz ljudska prava u kojima se prava pojedinca (kao što je primjerice privatnost) suprotstavljaju javnom interesu pri čemu se treba opredijeliti hoće li se pravo pojedinca shvatiti kao dio javnog interesa (u širem smislu) ili kao nešto što je protivno javnom interesu.

2. Druga vrsta neslaganja odnosi se na institucionalno ograničenje sudačke funkcije, posebice na razlikovanje između formalnog i sadržajnog rasuđivanja u smislu opreke između rasuđivanja sukladno tradicionalnim vrijednostima vladavine prava i rasuđivanja prema ishodima odnosno rezultatima koji se žele (trebaju) postići. Oba se pristupa mogu jednako dobro braniti kao sredstvo za spajanje različitih ljudskih vrijednosti putem međusobnih ustupaka između suprotstavljenih zahtjeva stabilnosti i zahtjeva promjene koje traži ljudska priroda. Neslaganje o formalnom i sadržajnom načinu rasuđivanja pokazuje se osobito u kontekstu izbora između gramatičkog i teleološkog tumačenja te rasprave o ograničenjima sudskog aktivizma.

3. Treća vrsta razilaženja presijeca prve dvije vrste, a odnosi se na suprotnost između općih, tradicionalnih, a priori prihvaćenih načela, s jedne strane $\mathrm{i}$ pragmatičnog i uzročno-posljedičnog pristupa.

41 Kelemen, K., op. cit., str. 1357. 
4. U četvrtoj vrsti riječ je o tomu da između sudaca u osnovi ne postoji neslaganje, već se međusobne razlike sastoje samo u njihovu subjektivnom odmjeravanju ili predviđanju ishoda ili zaključaka koji proizlaze iz činjenica predmeta. $^{42}$

Bivši sudac američkoga Vrhovnog suda William Brennan ističe da je jedan od motiva za isticanje izdvojenog mišljenja ufanje „oporbenog“ suca da će sud u budućnosti ispraviti „pogrešku“ koju je po njegovu mišljenju učinio. Osim toga, izdvojeno mišljenje nije samo obična replika, već ono ukazuje na ozbiljnost i širinu provedene rasprave u kojoj su suci koji čine prevladavajuće mišljenje prisiljeni baviti se teškim pitanjima koje pred njih postavljaju ostali suci čije je mišljenje ostalo u manjini, što povećava kvalitetu konačne odluke. Namjera suca koji je dao izdvojeno mišljenje može biti i nagovještaj mogućeg uspjeha na višim sudskim razinama te davanje uputa i prijedloga strankama postupka o sadržajnom usmjerenju pravnog lijeka. U tom smislu Brennan izražava potpuno neslaganje s ocjenama da suci izdvajaju mišljenje iz vlastita samoljublja ili da se tako zapravo bave pisanjem fikcija. ${ }^{43}$

Slično tomu, Baird i Jacobi kao moguće razloge za izdvajanje mišljenja navode: (1) pokušaj uvjeravanja većine da je pogriješila u donošenju odluke, (2) davanje signala strankama sudskog postupka (konkretnim i potencijalnim) o načinu na koji trebaju pravno uobličiti svoj zahtjev u budućim istovjetnim ili sličnim slučajevima radi povećanja izgleda za uspjeh u postupku te (3) stvaranje temelja za buduću izmjenu sudske prakse. ${ }^{44}$

No razlike i neslaganja između sudaca koji zajedno odlučuju kao članovi sudskog tijela nemaju uvijek za posljedicu izdvajanje mišljenja. Štoviše, u određenim okolnostima suci izbjegavaju izraziti izdvojeno mišljenje čak i kad se uopće ne slažu s većinskim mišljenjem. Takvu pojavu Epstein i kolege nazivaju „odbojnošću prema izdvajanju mišljenja“ (dissent aversion). Njihovo je istraživanje pokazalo da za izdvajanje mišljenja postoje različiti poticaji i pobude te da odluka suca o tomu ovisi o njegovu profesionalnom opterećenju, procjeni ugrožavanja kolegijalnih odnosa, mogućem utjecaju na buduću promjenu sudske prakse, ideološkom sastavu suda, važnosti slučaja i stupnju privrženosti suda sudskoj praksi odnosno presedanima. ${ }^{45}$

42 Alder, J., op. cit., str. 227-232.

43 Brennan, W. J., In Defense of Dissents, The Hastings Law Journal, vol. 37, str. 428 i 430, $<$ http://repository.uchastings.edu/...>, 25. veljače 2016. William J. Brennan bio je sudac Vrhovnog suda SAD-a (Associate Justice of the United States Supreme Court) u razdoblju od 1956. do 1990. godine.

44 Baird, V. i Jacobi, T., How the Dissent Becomes the Majority: Using Federalism to Transform Coalitions in the U.S. Supreme Court, Duke Law Journal, vol. 59, no. 2, 2009., str. 185 i 186, $<$ http://scholarship.law.duke.edu/... $>$, 21. prosinca 2015.

45 Epstein, L. i dr., Why (and When) Judges Dissent: a Theoretical and Empirical Analysis, Journal of Legal Analysis, vol. 3, no. 1, 2011., str. 135, <http://jla.oxfordjournals.org>, 14. siječnja 2016. 
Poseban problem, posebice u sustavima seriatim mišljenja, pitanje je koje pravno stajalište predstavlja obvezni presedan ako postoji više različitih mišljenja o razlozima donošenja odluke suda, a niti jedno pojedinačno izraženo mišljenje nema podršku potrebne većine sudaca. Kao odgovor na to pitanje teorija je razvila tri osnovne doktrine te niz prilično zamršenih metoda koje proizlaze iz njihovih kombinacija.

Osnovne metode rješenja tog problema su sljedeće:

1. doktrina najpribližnijeg stajališta (Narrowest Grounds Doctrine) prema kojoj u tom slučaju obvezni presedan predstavlja stajalište onog pojedinačnog potvrđujućeg (podudarnog) mišljenja koje najtješnje podupire donesenu odluku (who concurred in the judgement on the narrowest grounds) ${ }^{46}$

2. koncept dispozitiva po kojem presedan postaje jedino sama izreka odluke, dok su pojedinačna mišljenja ograničena na puko sredstvo uvjeravanja i nisu obvezna za niže sudove,

3. koncept većine po kojem presedan postaje stajalište onog potvrđujućeg (podudarnog) mišljenja koje podupire najveći broj sudaca (relativna većina, majority of the majority). ${ }^{47}$

Sljedeće pitanje vezano uz institut izdvojenog mišljenja odnosi se na njegov utjecaj na donošenje odluke suda. Iskustvena istraživanja pokazala su da već sama najava mogućeg izdvajanja mišljenja tijekom raspravljanja između sudaca rezultira preispitivanjem većinskog mišljenja što produljuje vrijeme potrebno za donošenje odluke. Jednako tako, sudska odluka koja zapravo predstavlja većinsko mišljenje, redovito je opširnija kad uz nju postoji izdvojeno mišljenje. ${ }^{48}$

Pravna teorija ipak se najviše bavi pitanjem o argumentima koji govore u prilog i protiv instituta sudačkog izdvojenog mišljenja. Pritom je od pitanja same dopuštenosti izdvojenog mišljenja još više prijeporno pitanje njegove javne objave.

Vezano uz ta pitanja Brennan ističe kako sud kao institucija predstavlja svojevrsni paradoks, jer istodobno označava organizaciju (kao jedinstveni subjekt) i njezine članove (kao pojedince). Kritike izdvojenog mišljenja zagovaraju primat organizacije u odnosu na njezine članove tvrdeći da je sud „legitimniji“ i

46 Tu je doktrinu uveo Vrhovni sud SAD-a u predmetu Marks v. United States iz 1977. godine u kojem se pozvao na najpribližnije stajalište iz nekoliko godina ranije donesene odluke u predmetu Memoirs v. Massachusetts. No ova doktrina ne rješava problem do kraja, jer se otvara novo pitanje o načinu određivanja onog pojedinačnog stajališta koje predstavlja „najpribližnije stajalište“. Iako teorija daje više različitih odgovora i na to pitanje, pojedini teoretičari nisu uvjereni u njezinu ispravnost i pouzdanost. Tako Friedman i njegove kolege smatraju da je riječ o krajnje čudnom pravilu koje predstavlja čistu fikciju. Friedman, B. i dr., op. cit., str. 139 i 145.

47 Ledebur, E. L., op. cit., str. 910-912.

48 Epstein, L. i dr., op. cit., str. 102-103 i 120. U tom smislu može se reći da sudac koji najavljuje izdvojeno mišljenje poprima ulogu ,vražjeg odvjetnika““ (advocatus diaboli) koji izaziva ili produbljuje raspravu, odnosno pronalazi slabosti, proturječnosti ili nesavršenosti u početnom stavu, čime pridonosi donošenju ispravne odluke i njezinu kvalitetnijem obrazloženju. 
vjerniji svojoj ulozi kada istupa jednim jedinim glasom. Međutim, iako je točno da jednoglasnost ističe snagu imperativa ustavnosti, ona nije sama po sebi vrlina sudbenog djelovanja. ${ }^{49}$

Kao argument u prilog instituta izdvojenog mišljenja najčešće se navodi njegova ukorijenjenost u dvije opće ustavne vrijednosti: slobodu izražavanja mišljenja i sudačku neovisnost.

Kad je riječ o slobodi izražavanja mišljenja ističe se da sucima mora biti omogućeno iskazivanje svojih misli i izražavanje protivljenja u slučaju kad se ne slažu s kolegama. Dopuštanje izdvajanja mišljenja unosi određenu mjeru demokratičnosti i slobode izražavanja u proces donošenja sudske odluke, jer tako svaki sudac u njemu sudjeluje u potpunosti, čak i kad na kraju odluku donosi većina. Izdvojena mišljenja izraz su kreativnosti, inovativnosti i izražaja pojedinog suca pa odnos sudstva prema praksi njihova objavljivanja ovisi o mjeri razumijevanja, prihvaćanja i praktične primjene slobode izražavanja. ${ }^{50}$

U tom smislu često citirani sudac Vrhovnog suda SAD-a Antonin Scalia navodi kako mogućnost napisati vlastito mišljenje, bez potrebe za prilagođavanjem u bilo kojoj mjeri, koje se više ili manje razlikuje od viđenja drugih kolega sudaca i usmjeriti se na pravni detalj koji drugi ne smatraju važnim te precizno izraziti i obrazložiti kritiku, ili bojazan, ili sumnju, ili predviđanje negativnog učinka u odnosu na većinsku odluku, predstavlja neusporedivo profesionalno zadovoljstvo. ${ }^{51}$

U odnosu na sudačku neovisnost ističe se da je davanje ovlasti sucima za izdvajanje njihova mišljenja preduvjet jamstva njihove neovisnosti. Ta neovisnost obuhvaća dva oblika: međusobnu neovisnost sudaca (jedan od drugog) i neovisnost sudstva od drugih grana vlasti. Mogućnost izdvajanja mišljenja sucima osigurava položaj u kojem su odgovorni samo svojoj savjesti, oslobođeni pritisaka da se priklone mišljenju koje ne podržavaju i koji im jamči ispunjenje obećanja danog sudačkom prisegom. ${ }^{52}$

Friedman i dr. ističu vrijednost izdvojenih mišljenja za budući razvitak prava. Dopuštajući izdvojena mišljenja, čak i kad ona zamućuju jasnoću zakona, sud putem njih optimalno uravnotežuje zahtjeve transparentnosti, legitimnosti, jasnoće, stabilnosti i ekonomičnosti. Pravo nije nikad statično, ono je uvijek usmjereno na budućnost. Vrsna izdvojena mišljenja šalju važne signale ne samo što pravo u danom trenutku jest već što ono u budućnosti može biti. U tom smislu izdvojena mišljenja svojevrsni su kompas za zakonske promjene. ${ }^{53}$

$\mathrm{Na}$ tom tragu Baird i Jacobi smatraju da se pojedina izdvojena mišljenja mogu objasniti kao znak da sudac koji je ostao u manjini nije odustao od svojih

49 Brennan, W., op. cit., str. 432.

50 Vitale, D., op. cit., str. 2-3 i 7.

51 Scalia, A., The Dissenting Opinion, Journal of Supreme Court History, vol. 19, no. 1, 1994. , str. 35, <htpp://onlinelibrary.wiley.com/...>, 4. ožujka 2016. Antonin Scalia bio je sudac Vrhovnog suda SAD-a (Associate Justice of the United States Supreme Court) od 1986., a preminuo je 13. veljače 2016., upravo u vrijeme pisanja ovoga rada.

52 Vitale, D., op. cit., str. 2.

53 Friedman i dr., op. cit., str. 104. 
argumenata i mišljenja te da svojim izdvojenim mišljenjem gradi temelj za mogući preokret u nekom budućem istovjetnom ili sličnom slučaju. Osim toga izdvojeno mišljenje može biti povod za tzv. certiorari postupak ${ }^{54}$ na višem sudu. Ono također može pomoći nezadovoljnoj stranci u iniciranju daljnjih postupaka ulaganjem pravnih lijekova. ${ }^{55}$

Slično tomu, Brennan navodi da vrijeme u kojem pojedino izdvojeno mišljenje može postati mišljenje većine ovisi o razvitku društva i dalekovidnosti sudaca kao pojedinaca. Pritom ističe primjer suca Johna M. Harlana ${ }^{56}$ koji se svojim izdvojenim mišljenjima zapravo nije obraćao samo kolegama sucima već čitavom društvu i što je još važnije, izvan okvira vremena budućim generacijama. Osim toga, smatra da iznošenje izdvojenog mišljenja nije samo pravo suca već je to, kada je riječ o važnom i dubokom neslaganju, ujedno i njegova obveza koja proizlazi iz odgovornosti prema načelu vladavine prava i drugim načelima na kojima počiva sudbena vlast. Kao što je sud dužan obrazložiti svoju odluku i objasniti zašto i kako je do nje došao, istu dužnost ima i sudac koji je izdvojio mišljenje. Stoga svaki sudac mora biti aktivni sudionik postupka i kad je potrebno mora napisati izdvojeno mišljenje i tako zabilježiti svoje razmišljanje. To nije čin njegova egoizma već njegova dužnost koju ne smije izbjegavati. ${ }^{57}$

U pravnoj literaturi navode se brojni primjeri slučajeva u kojima je izdvojeno mišljenje izjavljeno u određenom sudskom predmetu kasnije dovelo do promjene stajališta sudova i postalo većinsko mišljenje u drugom sudskom predmetu i daljnjoj praksi. Tako je primjerice u predmetu A Quantity of Copies of Books v. Kansas Vrhovni sud SAD-a odlukom iz 1964. godine donesenom većinom glasova sudaca uskratio pravo savezne države da svojim propisima uređuje postupanje prema određenoj literaturi s opscenim sadržajem tako da je smatra zabranjenom robom koja se može oduzeti i uništiti jednako kao i ilegalna alkoholna pića. Sudac John M. Harlan II ${ }^{58}$ izdvojio je mišljenje smatrajući da takva odluka nepotrebno spriječava savezne države u obuzdavanju širenja opscenih materijala, a isto je ponavljao i kasnije u istovjetnim predmetima. Nakon toga, u predmetu Paris Adult Theatre I v. Slaton Vrhovni sud je odlukom iz 1973. godine saveznim državama dao veliku slobodu u tom području, prihvaćajući pravno stajalište suca Harlana i citirajući njegova izdvojena mišljenja. ${ }^{59}$

54 Certiorari je poseban pravni institut u common law sustavu koji predstavlja pravo višeg suda da po vlastitoj diskrecijskoj odluci (Writ of Certiorari) preuzme slučaj nižeg suda. Taj postupak mogu predložiti i stranke u postupku (Petititon for Writ of Certiorari), ali sud prijedlog ne mora prihvatiti, jer nije riječ o pravu stranke, već o diskrecijskoj ocjeni samog suda. Postupak je osobito prisutan u praksi Vrhovnog suda SAD-a. Black's, op. cit., str. 241 i 242. Vidi i Smerdel, B. i Sokol, S., op. cit., str. 173.

55 Baird, V. i Jacobi, T., op. cit., str. 186. i 196.

56 Vidi supra u poglavlju 3.

57 Brennan, W., op. cit., str. 432 i 435-438.

58 Sudac John Marshall Harlan II. bio je sudac Vrhovnog suda SAD-a (Associate Justice of the United States Supreme Court) od 1955. do 1971.

59 Baird, V. i Jacobi, T., op. cit., str. 194. i 195. 
U spomenutom istraživanju Odbora za pravna pitanja Europskog parlamenta ${ }^{60}$ također se navode slični argumenti u prilog izdvojenih mišljenja: zaštita integriteta sudaca, moralne neovisnosti i slobode izražavanja, poboljšanje kvalitete sudskih odluka i njihove uvjerljivosti, pospješivanje transparentnosti te razvijanje dijaloga s drugim sudovima i slanje poruka za budućnost. ${ }^{61}$

Iako institut izdvojenog mišljenja ima brojne zagovornike, broj njegovih protivnika nije ništa manji niti su njihovi protuargumenti ili barem neki od njih bitno slabiji. Ocjene o izdvojenim mišljenjima kreću se u širokom rasponu. U najboljem slučaju shvaćaju se kao „svojstven način razmišljanja s vrijednošću i prolaznošću anegdote“, a u najgorem slučaju smatraju se „patološkim lomom u pravnom sustavu. “62

Protivnici izdvojenog mišljenja smatraju da je taj institut protivan načelu vladavine prava prema kojem sud ima svoj vlastiti institucionalni nastup koji je iznad pojedinačnih nastupa njegovih članova. Budući da u idealnom smislu vladavina prava nije vladavina ljudi (the rule of law is not the rule of men) ${ }^{63}$, izdvojeno mišljenje kao tekst njegova autora (pojedinca) predstavlja prijetnju odluci suda (većine), jer ta dva akta ne mogu biti istodobno prihvaćena pa stoga ono mora ostati skriveno. Izdvojena mišljenja podrivaju jasnoću institucionalnog istupanja suda i čini upitnim odnos između sudskih odluka i pravne sigurnosti. ${ }^{64}$

Istraživanje Odbora za pravna pitanja Europskog parlamenta kao glavne argumente protiv izdvojenih mišljenja utvrdilo je zaštitu autoriteta suda i njegovih sudaca, čuvanje neovisnosti sudaca od neprimjerenih političkih pritisaka, osiguranje jasnoće i nedvosmislenosti donesenih odluka i očuvanje međusobne kolegijalnosti sudaca. ${ }^{65}$

U pravnoj literaturi protiv izdvojenih mišljenja također se obično ističu isti ili slični argumenti: 1) moguće slabljenje uvjerljivosti pravnih institucija i gubitak povjerenja javnosti (izdvojeno mišljenje samo po sebi ili u nekom kontekstu nameće pitanje uvjerljivosti, vjerodostojnosti i autoriteta većinski usvojene sudske odluke), 2) slabljenje pravne sigurnosti (izdvojeno mišljenje može unijeti dodatnu zbunjenost u već ionako složeno područje prava i na neprihvatljiv način oslabiti doktrinu stare decisis ${ }^{6}$ ), 3) moguće zloupotrebe sudske vlasti (izdvojeno mišljenje sudac može iskoristiti za svoju vlastitu promociju, za stjecanje određenog položaja formiranjem neformalnih saveza s drugim sucima ili za omalovažavanje drugih kolega sudaca) i 4) neučinkovitost (izdvojena mišljenja ne povećavaju opterećenje samo suca koji je

60 Vidi supra, bilj. 37.

61 Raffaelli, R., op. cit., str. 7.

62 Alder, J., op. cit., str. 221 i 222.

63 Riječ je o postavci koja se ističe u mnogim presudama američkoga Vrhovnog suda, između ostalih i u ranije spomenutoj presudi Marbury v. Madison (,, The Government of the United States has been emphatically termed a government of laws, and not of men."). Marbury v. Madison, str. 163., vidi supra, bilj. 29.

64 Stack, K., op. cit., str. 2238-2240 i 2258.

65 Raffaelli, R., op. cit., str. 7.

66 Vidi supra, bilj. 32. 
izdvojio mišljenje već i ostalih sudaca, jer moraju utrošiti više napora i vremena za obrazloženje svoje odluke, a osim toga povećavaju se i troškovi objave odluke). ${ }^{67}$

Friedman i kolege navode da je najjači i najčešći argument koji se ističe protiv izdvojenih mišljenja ocjena da ona razaraju pravnu jasnoću. ${ }^{68}$

To stajalište, između ostalih, zastupa i Ledebur koji navodi kako izdvojeno mišljenje dovodi do podijeljenosti suda pa stoga njegove odluke nemaju potpuno jasno značenje i vrijednost presedana te dovode do pomutnje među nižim sudovima. Ističe da je upravo Marshallovo uvođenje metode donošenja jedinstvene odluke suda većinskim odlučivanjem omogućilo Vrhovnom sudu SAD-a da se postavi na položaj glavne snage unutar sudbene grane vlasti uz bok izvršnoj i zakonodavnoj grani vlasti. ${ }^{69}$

No pored navedenih, pojedini autori navode i argument mogućeg negativnog utjecaja izdvojenog mišljenja na odnose kolegijalnosti između sudaca. ${ }^{70} \mathrm{~S}$ jedne strane suci čije se mišljenje na prihvaća često se povlače i ne pridonose raspravi i sadržaju sudske odluke, već se usredotočuju na kreiranje svog izdvojenog mišljenja. S druge strane suci koji zastupaju većinsko mišljenje mogu pogrešno shvatiti izdvajanje mišljenja kao „neprijateljski čin“ s ciljem osporavanja njihove sposobnosti i ugleda te mogu na različite načine uzvratiti, omalovažiti ili isključiti neistomišljenika u okvirima sudačke dužnosti. ${ }^{71}$

Iako sudac koji izrazi drukčije mišljenje na bilo koji način u pravilu ne gubi zbog toga svoj položaj i ugled među kolegama, barem ne u sustavima s tradicijom izdvajanja mišljenja, u pravnoj literaturi zabilježen je slučaj u kojem je predsjednik engleskog Prizivnog suda (Master of the Rolls) ${ }^{72}$, predsjedajući tročlanim sudskim vijećem, nakon što se druga dvojica sudaca nisu složila s njegovim mišljenjem da predmetnu žalbu treba usvojiti, arogantno zaključio da će žalba ipak biti usvojena, a njima naložio da se međusobno dogovore koji će od njih dvojice izdvojiti

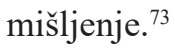

U odnosu na dopuštenost objavljivanja izdvojenih mišljenja u javnosti, to je pitanje jednako zanimljivo s teorijskoga kao i s praktičnog aspekta. Pojedini autori smatraju da bi izdvojena mišljenja trebala biti samo u internom kolanju između sudaca, a ne bi ih trebalo javno objavljivati. Tako bi se iskoristila vrijednost izdvojena mišljenja u „brušenju“ mišljenja većine, a istodobno bi se sačuvao dojam

67 Vitale, D., op. cit., str. 4-6.

68 Friedman, B. i dr., op. cit., str. 129.

69 Ledebur, E. L., op. cit., str. 901 i 902.

70 Raffaelli, R., op. cit., str. 11, Epstein, L. i dr., op. cit., str. 135., Brennan, W., op. cit., str. 435.

$71 \mathrm{U}$ tom smislu zanimljivo je da se u engleskom jeziku riječ dissenter kojom se naziva sudac koji izdvoji mišljenje, koristi u značenju ,čovjek drugih nazora“, „,̌ovjek koji drukčije misli“, „oporbenjak“, ali i u značenju „otpadnik“ i „sektaš“. Bujas, Ž., Veliki englesko-hrvatski rječnik, Nakladni zavod Globus, Zagreb, 2005., str. 241.

72 Master of the Rolls naziv je za predsjednika Prizivnog suda (Court of Appeal) u Engleskoj, a nekada je taj naziv imao sudac odgovoran za registar i arhiv. Black's, op. cit., str. 998.

73 Brennan, W., op. cit., str. 429. 
čvrstoće uvjerenja i sigurnosti. ${ }^{74}$

Suprotno tomu, Lynch smatra kako je mogućnost da sudac objavi svoje mišljenje kojim ne prihvaća obrazloženje svojih kolega sudaca, smatrajući da je donošenjem odluke većina pogriješila, ključni pokazatelj snažnog i neovisnog sustava sudstva te da je postojanje sudskih presuda s izdvojenim mišljenjima jedan od čimbenika koji potvrđuje jamstvo o ekipiranosti sudova sucima koje ne obvezuje ništa snažnije od vlastita osobnog poštovanja zakona. Potpuno i otvoreno iznošenje svih razloga za donošenje sudske odluke nužan je uvjet obavljanja sudbene vlasti, a taj zahtjev uključuje i objavljivanje izdvojenog mišljenja. Osim toga, odsutnost drukčijeg mišljenja ne spriječava analizu i kritiku sudske odluke od strane političara, medija i zainteresiranih komentatora. ${ }^{75}$

Najpotpuniji pregled argumenata koji govore u prilog i protiv objavljivanja izdvojenih mišljenja koji se može naći u pravnoj literaturi daje Alder. Kao argumente za objavljivanje on ističe sljedeće:

1. sama spoznaja o mogućnosti objave izdvojenog mišljenja jamči jednak odnos prema svim članovima sudskog vijeća i njihovim pojedinačnim stajalištima te se tako ne slabi, već dapače jača njihova kolegijalnost,

2. objava izdvojenog mišljenja jača pouzdanje u sudstvo, jer potiče većinu na oštroumnije rasuđivanje i tako osigurava donošenje dobro promišljene i neovisne odluke uz punu odgovornost njezinih donositelja,

3. objava izdvojenog mišljenja spaja slobodu izražavanja kao tradicionalnu vrijednost i osobnu savjest kao unutarnju vrijednost,

4. objavljeno izdvojeno mišljenje može razotkriti slabosti u pravnom uređenju i tako utjecati na njegove promjene u budućnosti (u SAD-u to se naziva „proročanskom“ odnosno ,prosvjetnom“ ulogom),

5. objava izdvojenog mišljenja može pomoći u pojašnjenju i razumijevanju spornog pitanja, jer se argumenti na kojima se zasniva sudska odluka ponekad mogu lakše sagledati kroz suprotno gledanje.

S druge strane, navodi sljedeće argumente koji govore protiv javnog objavljivanja izdvojenog mišljenja:

1. vanjski izgled jedinstva suda u donošenju odluke općenito se smatra osloncem autoriteta pravnog sustava i pouzdanja u pravo, dok objava izdvojenog mišljenja slabi učinak većinskog mišljenja i tako umanjuje povjerenje u odluku suda,

2. objavljivanje izdvojenih mišljenja unosi nesigurnost u pravni sustav i na neprihvatljiv način slabi doktrinu stare decisis ${ }^{76}$,

3. objava izdvojenog mišljenja obično ima slab učinak i stoga bespotrebno troši kapacitete te uglavnom služi samoreklamiranju o javnom trošku,

4. izdvojeno mišljenje može zamrsiti slučaj o kojem se treba odlučiti i unijeti smetenost u razmišljanje većine,

74 Alder, J., op. cit., str. 245.

75 Lynch, A., op. cit., str. 81, 92 i 103.

76 Vidi supra, bilj. 32. 
5. tajnost odnosno skrivenost pojedinačnih mišljenja čuva sudsku neovisnost štiteći svakoga pojedinog suca od političkog uplitanja. ${ }^{77}$

Iako se argumenti koji govore protiv izdvojenih mišljenja i njihovog objavljivanja ne mogu a priori odbaciti i zanemariti, uz različita veća ili manja ograničenja takvo postupanje afirmiralo se u mnogim državama, osobito u postupanju ustavnih sudova odnosno drugih najviših sudova koji obavljaju funkcije ustavnog sudovanja. No s obzirom na snagu i ozbiljnost argumenata protiv izdvojenih mišljenja i osobito njihovog objavljivanja, čak i teoretičari i praktičari koji se za njih zalažu smatraju da u toj praksi moraju postojati određena pravila odnosno ograničenja.

Tako Brennan smatra da izdvojeno mišljenje samo za sebe nema vrijednost te da sudac ne treba objavljivati beznačajna neslaganja s većinom. U tom smislu ničija dužnost nije samo dizati galamu već svatko, a osobito suci trebaju glasno istupiti kad su uvjereni da je to potrebno za ostvarivanje rezultata odnosno cilja postavljenog ustavnim pravilima. ${ }^{78}$

Alder također naglašava da bi izdvojeno mišljenje trebalo koristiti rijetko i strateški te da u tom smislu suci trebaju biti suzdržani. Izdvajanje mišljenja treba koristiti samo ako postoji zaista vrijedan razlog za to. Ono bi trebalo biti dopušteno u stvarima javnog prava, a u području privatnog prava samo iznimno. ${ }^{79}$

Raspravama o tom pitanju najbogatija je njemačka pravna literatura u kojoj se, pored ostalog, pokušalo odrediti konkretna pravila i uvjete za objavljivanje izdvojenih mišljenja i za njihov sadržaj, kao što su primjerice sljedeća pravila:

- objavljivanje izdvojenih mišljenja treba ograničiti samo na predmete od načelnog odnosno temeljnog interesa,

- izdvojena mišljenja ne smiju biti pogrešno protumačena kao način polemiziranja protiv odluke sudskog tijela odnosno suda i njezina obrazloženja,

- uloga objave izdvojenog mišljenja nije osporavanje i bitka s većinskim stajalištem, već je njezina namjera što je moguće uvjerljivije i preciznije iznošenje argumenata protiv njega. ${ }^{80}$

Iako je izdvojeno mišljenje široko prihvaćeno kao oličenje sudačke slobode i transparentnosti sudskog odlučivanja, treba priznati da postoje situacije u kojima je u donošenju odluke iznimno važno postići jednoglasnost sudaca, jer se tako maksimalno osnažuje njezin legitimitet i šalje snažna poruka o nepostojanju alternative, a to bitno utječe na njezino prihvaćanje od strane stranaka postupka, nižih sudova i opće javnosti. Kao primjer često se navode odluke američkoga Vrhovnog suda u predmetima Brown v. Board of Education iz 1954. godine i Cooper v. Aaron iz 1958. godine.

77 Alder, J., op. cit., str. 240-243.

78 Brennan, W., op. cit., str. 435 i 438.

79 Alder, J., op. cit., str. 244.

80 Mavčić, A., op. cit., str. 5. 
Prvi predmet odnosio se na pitanje rasne segregacije u sustavu obrazovanja u gradu Topeki gdje je Odbor za školstvo (The Topeca Board of Education) na temelju zakona države Kansas iz 1879. godine odvojio škole za osnovno obrazovanje djece crne i bijele rase. Iako je u već početku postupka većina sudaca smatrala da odluka Odbora nije u skladu s Ustavom, bilo je sudaca koji su imali drukčije mišljenje. Tadašnji predsjednik Suda Earl Warren ${ }^{81}$ uložio je veliki napor da izbjegne izdvojena mišljenja, smatrajući da bi unatoč tome što bi odluka donesena većinom formalno imala istu pravnu snagu, izdvojena mišljenja mogli iskoristiti zagovaratelji segregacije kao priznavanje legitimnosti suprotnih argumenata te da je radi održanja integriteta Suda i izbjegavanja masovnog otpora u državama američkoga juga odluku potrebno donijeti jednoglasno. Sud je nakon dugih rasprava i uvjeravanja konačno donio odluku kojom je oborio koncept separate but equal iz predmeta Plessy v. Ferguson ${ }^{82}$ i zauzeo pravno stajalište prema kojem je segregacija sama po sebi štetna za učenike crne rase i stoga neustavna, bez obzira na to što su posebne škole za djecu obje rase jednake u kvaliteti prostorija i učitelja.

$\mathrm{U}$ drugom predmetu također je bila riječ o segregaciji u školama, ovaj put $\mathrm{u}$ saveznoj državi Arkansas, u kojoj je nakon odluke Vrhovnog suda u slučaju Brown v. Board of Education izmijenjen njezin Ustav kako bi se osujetio plan desegregacije. $\mathrm{U}$ ovom predmetu pristaše segregacije tvrdili su da savezne države imaju ovlast poništiti federalne zakone i odluke federalnih sudova, ako smatraju da one nisu ustavne pa tako i odluku Vrhovnog suda u slučaju Brown v. Board of Education. Vrhovni sud jednoglasno je donio odluku kojom je ocijenio ustavno nedopustivim primjenu zakona i propisa kojima se oduzimaju jednaka prava učenicima crne rase. No, osim toga Vrhovni sud odbacio je tvrdnje vlasti Arkansasa i pozivajući se na klauzulu o supremaciji iz članka VI. Ustava SAD-a (Supremacy Clause) $)^{83}$ prema kojoj je federalni Ustav najviši pravni akt u SAD-u i na odluku Vrhovnog suda SAD-a u predmetu Marbury v. Madison ${ }^{84}$ prema kojoj je Vrhovni sud krajnji odnosno odlučni tumač Ustava, izrazio stajalište da je presedan postavljen u predmetu Brown v. Board of Education obvezan za sve savezne države, bez obzira na eventualnu protuslovnost njihovih zakona pa tako u konkretnom slučaju i za vlasti savezne države Arkansas.

Mišljenje o potrebi za usklađenjem tumačenja sudaca $u$ određenim okolnostima iznosi i Dworkin. Razvijajući koncepciju prema kojoj se sudska kao

81 Sudac Earl Warren bio je predsjednik Vrhovnog suda SAD-a (Chief Justice of the United States) od 1953. do 1969. godine.

82 Vidi supra u poglavlju 3.

83 Riječ je o članku VI. Ustava SAD-a koji propisuje da federalni Ustav, zakoni i ugovori predstavljaju najviše pravo SAD-a (supreme law of the land) i imaju pravnu superiornost $\mathrm{u}$ odnosu na bilo koje odredbe ustava ili zakona saveznih država koje su s njima u sukobu. Black's, op.cit., str. 1481. Smisao ove klauzule je u potrebi postojanja mehanizma koji odgovara na pitanje primjene prava u slučajevima međusobnog sukoba propisa različitih razina vlasti (federalnih vlasti i vlasti saveznih država). Bačić, A. i Bačić, P., Konstitucionalizam i federalizam, Europske studije, vol. 1, br. 1, 2015., str. 65.

84 Vidi supra, bilj. 29 i 63. 
i zakonodavna vlast trebaju voditi načelom integriteta (the principle of integrity) s osnovnim zahtjevom da obnašatelji tih funkcija stvaraju i tumače pravo tako da se ono može primjenjivati dosljedno i usklađeno, navodi kako se sudac ponekad mora prilagođavati da bi dobio glasove drugih sudaca i da bi sud donio zajedničku odluku koja bi bila prihvatljiva okruženju odnosno društvu i mogla djelovati u duhu ustavnih načela. ${ }^{85}$

\section{IZDVOJENO MIŠLJENJE U HRVATSKOM PRAVNOM SUSTAVU}

U Republici Hrvatskoj sudovi sude na temelju Ustava i zakona. Iako važnu ulogu ima i sudska praksa, nije riječ o sustavu presedana, jer odluke viših sudova obvezuju sudove nižih stupnjeva samo snagom pravnog argumenta te se tako postiže i učinak ujednačavanja sudske prakse. ${ }^{86}$

U pravnim stvarima iz sudske nadležnosti u prvom stupnju u pravilu sudi sudac pojedinac. U kojim slučajevima sudovi u prvom stupnju sude u vijeću određuje se zakonom. U višem stupnju sudovi u pravilu sude u vijeću, a iznimno i u tom postupku može suditi sudac pojedinac. Broj članova vijeća koji odlučuju o pojedinim predmetima različit je i ovisi o vrsti postupka.

U parničnom postupku sporove u prvom stupnju sudi sudac pojedinac, $\mathrm{u}$ drugom stupnju vijeće sastavljeno od troje sudaca, a u postupku povodom revizije u vijeću sastavljenom od petero sudaca, ako zakonom nije drukčije određeno. U postupcima u kojima sudi vijeće za donošenje odluke potrebna je većina glasova. O vijećanju i glasovanju sastavlja se poseban zapisnik koji sadrži tijek glasovanja i odluku koja je donesena. Odvojena mišljenja mogu se unijeti u zapisnik ili priključiti zapisniku. Zapisnik o vijećanju i glasovanju zatvara se u poseban omot i može ga razgledati samo viši sud kad rješava o pravnom lijeku. U tom slučaju zapisnik se nakon razgledanja ponovno zatvara u poseban omot s naznakom da je razgledan. ${ }^{87}$ Iz navedenih zakonskih odredbi proizlazi da u parničnom postupku postoji mogućnost izjavljivanja izdvojenog mišljenja suca, ali ono nije dio sudske odluke i nije dostupno čak ni strankama postupka već samo višem sudu u postupku instancijskog preispitivanja odluke.

U kaznenom postupku sudovi sude u vijećima sastavljenim od troje ili petero sudaca. Odluke se donose većinom glasova članova vijeća. Na zahtjev člana vijeća koji je izdvojio glas, njegovo pisano obrazloženje prilaže se pisanoj

85 Dworkin, R., „Law's empire“, The Belknap Press of Harvard University Press, Cambridge (USA) i London (UK), 1986., str. 380.

86 U nekim postupcima postoji obveza sudova nižeg stupnja da prihvate i pravna stajališta, ali samo kad je riječ o stajalištima Vrhovnog suda. Takva obveza postoji primjerice u Zakonu o parničnom postupku (članak 394.a).

87 Zakon o parničnom postupku, NN br. 53/1991, 91/1992, 112/1999, 129/2000, 88/2001, 117/2003, 88/2005, 2/2007, 96/2008, 84/2008, 123/2008, 57/2011, 25/2013 i 89/2014, članci 41., 44., 128. i 131. 
odluci. Vijećanje i glasovanje obavljaju se u nejavnom zasjedanju. Podatci o tijeku vijećanja i glasovanju su tajni, osim ako sudac koji je izdvojio mišljenje zatraži da se ono objavi. ${ }^{88}$

Na prekršajnom sudu odluke donosi sudac pojedinac, osim ako je zakonom propisano da odluku donosi vijeće od troje sudaca. Visoki prekršajni sud odluke donosi u vijeću od troje sudaca, osim ako zakonom nije drukčije propisano. Odluke vijeća donose se nakon usmenog vijećanja i glasovanja, a odluka je donesena kad je za nju glasovala većina članova vijeća. Vijećanje i glasovanje obavlja se u nejavnom zasjedanju o čemu se vodi poseban zapisnik koji potpisuju predsjednik i članovi vijeća i zapisničar te taj zapisnik ostaje u spisu predmeta. ${ }^{89}$ Mogućnost izdvajanja mišljenja i postupanje s pisanim obrazloženjem nije posebno uređeno.

U upravnim sporovima pred upravnim sudovima odlučuje sudac pojedinac, a Visoki upravni sud odlučuje u vijeću od troje sudaca, osim o zakonitosti općih akata kada odlučuje u vijeću od petero sudaca. Vijeće donosi presudu većinom glasova. O vijećanju i glasovanju vodi se poseban zapisnik koji potpisuju svi članovi vijeća i zapisničar. ${ }^{90}$ Iako izdvajanje mišljenja u postupku donošenja odluke u upravnom sporu nije uređeno, objektivno nema razloga zbog kojeg ta mogućnost ne bi bila dopuštena na jednak način kao i u postupcima na drugim sudovima. Tako Đerđa i Šikić izričito navode da član vijeća koji se ne slaže s drugim članovima o određenom pitanju ili odluci može izdvojiti i dodatno obrazložiti svoje mišljenje, što se unosi u zapisnik o vijećanju i glasovanju. U tom zapisniku može se i samo utvrditi da je određeni član izdvojio mišljenje te da je ono u pisanom obliku priloženo uz zapisnik. ${ }^{91}$

Prema Sudskom poslovniku kojim se propisuju osnove za poslovanje u sudovima, zapisnik o vijećanju i glasovanju nakon dovršene rasprave sastavlja se na posebnom listu, a potpisuju ga članovi vijeća i zapisničar. Nakon toga zapisnik se ulaže u posebni omot na kojem se s vanjske strane stavlja oznaka „Zapisnik o vijećanju s rasprave od...", upisuje se poslovni broj spisa predmeta i stavlja okrugli pečat suda. Omot sa zapisnikom o vijećanju i glasovanju ulaže se iza raspravnog zapisnika u spis predmeta u kojem se odlučivalo. Kad se po pravilima odgovarajućeg postupka o vijećanju i glasovanju ne sastavlja poseban zapisnik, na izvornike donesenih odluka stavlja se, ispod teksta, štambiljem bilješka o vijećanju koja sadrži dan vijećanja, ime i prezime predsjednika i članova vijeća, a posebno izvjestitelja, kao i podatak je li odluka donesena jednoglasno. ${ }^{92}$ Sudskim poslovnikom, međutim, nije uređeno postupanje s izdvojenim mišljenjima.

88 Zakon o kaznenom postupku, NN br. 152/2008, 76/2009, 80/2011, 91/2012, 143/2012, 56/2013, 145/2013 i 152/2014, članci 19.b, 19.d, 19.f, 164. i 166.

89 Prekršajni zakon, NN br. 107/2007, 39/2013, 157/2013 i 110/2015, članci 97. i 144.

90 Zakon o upravnim sporovima, NN br. 20/2010, 143/2012 i 152/2014, članci 14. i 75.

91 Đerđa, D. i Šikić, M., Komentar Zakona o upravnim sprovima, Zagreb, Novi informator, 2012., str. 248. Riječ je, doduše, o komentaru teksta Zakona prije izmjena i dopuna iz prosinca 2012. (NN, br. 143/2012) kojima su na prvostupanjskim upravnim sudovima uvedeni postupci koje vodi sudac pojedinac umjesto sudskog vijeća. Međutim, to ne mijenja stvar u odnosu na postupak pred Visokim upravnim sudom.

92 Sudski poslovnik, NN, br. 37/2014, 49/2014, 8/2015, 35/2015 i 123/2015, članci 130. i 132. 
U praksi izdvojena mišljenja na redovnim i specijaliziranim sudovima $u$ postupcima u kojima odlučuje sudsko vijeće vrlo su rijetka. U slučaju kad sudac izdvoji mišljenje, ono se zajedno sa zapisnikom o vijećanju i glasovanju zatvara u posebni omot. Iz same presude odnosno rješenja nije vidljivo je li doneseno jednoglasno ili većinom glasova. Eventualna izdvojena mišljenja u pravilu se ne objavljuju i nisu dostupna čak ni strankama u postupku.

Iznimku od toga pravila predstavlja praksa Vrhovnog suda Republike Hrvatske koji u kaznenim postupcima na temelju članka 164. stavka 1. Zakona o kaznenom postupku, uz svoju odluku na zahtjev suca objavljuje i njegovo izdvojeno mišljenje. Odluke i izdvojena mišljenja objavljuju se na mrežnoj stranici Vrhovnog suda (http://sudska praksa.vsrh.hr), a dostupni su i na nekim pravnim portalima (primjerice www.iusinfo.hr). ${ }^{93}$

\section{PRAKSA USTAVNOG SUDA REPUBLIKE HRVATSKE}

Pod ustavnim sudovanjem u širem smislu razumijeva se rješavanje u sudskom obliku o određenim ustavnopravnim pitanjima, a u cilju zaštite ustava. U užem smislu riječi pod ustavnim sudovanjem razumijeva se ispitivanje ustavnosti zakona od strane suda. ${ }^{94}$

Najrašireniji modeli ustavnog nadzora jesu: 1) europsko-kontinentalni ili austrijski model ustavnog nadzora, u kojem se ustavnopravnim pitanjima bave specijalizirani ustavni sudovi s posebno kvalificiranim sucima ili posebni odjeli vrhovnih ili viših sudova (koncentrirani ustavni nadzor) u posebnom postupku (principaliter) i 2) američki model (model sudbenog nadzora, judicial review), $\mathrm{u}$ kojem se ustavnim pitanjima bave svi redovni sudovi (decentralizirana, difuzna, odnosno disperzivna kontrola) u redovitom sudskom postupku (incidenter). ${ }^{95}$

Europsko-kontinentalni ili austrijski model ustavnog nadzora temelji se na Kelsenovom učenju prema kojem se ovlast ispitivanja ustavnosti zakona i njihova stavljanja izvan snage povjerava posebnom ustavnom sudu kao više ili manje

93 Tako su primjerice objavljena izdvojena mišljenja uz presudu I Kž Us 35/11 od 30. studenoga 2011., rješenje Kž eun 19/14-4 od 8. i 15. travnja 2014., rješenje II Kž 248/15-4 od 8. srpnja 2015. i rješenje II Kž 411/15-4 od 2. prosinca 2015.

94 Prema Krbeku, ustavnim sudovanjem: „, načelo vladavine prava odnosno sudovanje postiže svoju kulminaciju; treću i najvišu fazu u svom razvoju, kojeg je prva i osnovna faza bilo civilno i kazneno sudovanje, a druga faza upravno sudovanje. Kao što upravno sudovanje osigurava načelo zakonitosti nad određenim aktima javne vlasti, ustavno sudovanje osigurava načelo ustavnosti, supremaciju ustava nad zakonom i drugim aktima. Ustavnim sudovanjem želi se, pravnim sredstvima, osigurati da vršenje i samih najviših drž. funkcija bude u skladu s ustavom." Krbek, op. cit., str. 6-7.

95 Prema statističkim podatcima krajem prošlog tisućljeća u svijetu je postojalo 217 različitih sustava nadzora ustavnosti. Od toga 116 sustava pripada europsko-kontinentalnom modelu, a 53 američkom modelu, dok ostatak pripada različitim drugim modelima. Harutyunyan, G. i Mavčić, A., The constitutional review and its development in the modern world (a comparative constitutional analysis), Yerevan - Ljubljana, Hayagitak, 1999., str. 287-288. 
ekskluzivna funkcija, dok ostali redovni sudovi imaju samo pravo pokretanja postupka ocjene ustavnosti zakona kojeg smatraju neustavnim. Mogućnost ukidanja zakona kojeg je donijelo zakonodavno tijelo od strane ustavnog suda znači da pored „pozitivnog“" postoji i ,negativni“" zakonodavac. ${ }^{96}$

No, u suvremenim uvjetima uloga ustavnog sudovanja proširena je izvan Kelsenovog modela. Tako Omejec ističe kako defenzivna uloga ustavnog suda u obrani ustava danas više nije njegova jedina niti najvažnija uloga. Pored nje, sve značajnije mjesto dobiva interpretativna uloga ustavnog suda koja, za razliku od njegove izvorne defanzivne funkcije obrane ustava, ima pozitivan utjecaj u promicanju općih mjerila i smjernica za djelovanje javnih vlasti. Tako interpretacijom ustava, ustavni sudovi imaju važnu ulogu u kreiranju cjelokupnog pravnog poretka. Moderni je konstitucionalizam, međutim, otišao još dalje i ustavnim sudovima dao novu ulogu zaštite temeljnih prava i sloboda zajamčenih ustavom. ${ }^{97}$ No, osim toga, u novije se vrijeme, osobito za ustavne sudove u postsocijalističkim i postkomunističkim državama ističe i njihova transformativna uloga. ${ }^{98}$

Iz tih uloga proizlazi i posebna narav ustavnih sudova koja ih čini institucijom sui generis. Riječ je naime o sudovima koji u svom postupanju sjedinjuju sudsku funkciju (rješavanje sporova) i političku funkciju (uređenje društvenih odnosa) ${ }^{99}$

$\mathrm{S}$ obzirom na to, ustavni suci u određenim složenim, teškim i osjetljivim predmetima ponekad moraju uzimati u obzir i elemente koje nužno ne ulaze u okvir prava u klasičnom smislu. U tom smislu upravo u ustavnom sudovanju dolazi do izražaja Dworkinova koncepcija po kojoj suci radi donošenja odluke u teškim predmetima, trebaju pribjeći izvorima koje formalisti mogu smatrati izvanpravnim, kao što su primjerice koncepti pravednosti i opće dobrobiti. Ta nužnost obraćanja izvorima mimo prava i izvan prethodno stvorene prakse, podrazumijeva postojanje zakonodavne odgovornosti (legislative responsibilities) sudaca koju oni trebaju otvoreno prihvatiti. ${ }^{100}$

Sukladno tomu ustavni suci manje su vezani uz tradicionalni sudački mentalitet od redovnih sudaca, jer u argumentaciji svojih stavova koriste drukčije interpretativne tehnike i stilove. To je jedan od razloga zbog kojeg se u kontinentalnoj Europi izdvojena mišljenja puno više koriste u postupcima na

96 Kelsen, H., General Theory of Law and State, Clark, New Jersey (USA), The Lawbook Exchange ltd., 2009., str. 268-269.

97 Omejec, J., O potrebnim promjenama u strukturi hrvatskog ustavnog sudovanja, u: Barbić, J. (ur.), Hrvatsko ustavno sudovanje, Zagreb, HAZU, 2009., str. 31-32.

98 U tom smislu Omejec ističe da je zadaća ,ustavnih sudova u europskim postsocijalističkim $i$ postkomunističkim državama, dakle, postupno usmjeravati, u optimalnoj mjeri, pravni poredak prema idealima utjelovljenim u njihovim tranzicijskim ustavima." Pritom se moraju bezuvjetno pokoravati načelu samoograničenja te istodobno paziti da „, ne skliznu $u$ nedopustiv politički konformizam". Omejec, J., Novi europski tranzicijski ustavi i transformativna uloga ustavnih sudova, u: Bačić, A. (ur.): Dvadeseta obljetnica Ustava Republike Hrvatske, Zagreb, HAZU, 2011., str. 82.

99 Kelemen, K., op. cit., str. 1352.

100 Dworkin, R., op. cit., str. 115-117 i 126-129. 
ustavnim sudovima u odnosu na ostale sudove. Pritom ona mogu imati vrlo važnu ulogu u obogaćenju rasprava o ustavnopravnim pitanjima i bitno pomoći razvitku ustavnog prava. ${ }^{101}$

Hrvatski sustav ustavne kontrole ustrojen je na osnovama europskokontinentalnog modela ustavnog nadzora.

Položaj i nadležnost Ustavnog suda Republike Hrvatske (u daljnjem tekstu: Ustavni sud) neposredno uređuje Ustav Republike Hrvatske ${ }^{102} \mathrm{u}$ posebnoj Glavi V. pod nazivom "Ustavni sud Republike Hrvatske". Ustavni sud ne pripada nijednoj grani državne vlasti, što je razvidno i iz strukture teksta Ustava. Odredbe o Ustavnom sudu (Glava V. Ustava) odvojene su od odredaba koje uređuju ustrojstvo državne vlasti temeljeno na načelu diobe vlasti (Glava IV. Ustava). Drugim riječima, Ustavni sud ne pripada ni sudbenoj ni zakonodavnoj niti izvršnoj grani vlasti. On je najviše ustavno tijelo Republike Hrvatske koje jamči poštovanje i primjenu Ustava te je zbog osobitog ustavnog položaja neovisan o svim tijelima državne vlasti.

Djelovanje Ustavnog suda temelji se na odredbama Ustava i Ustavnog zakona o Ustavnom sudu Republike Hrvatske (u daljnjem tekstu: UZUS) ${ }^{103}$ koji ima snagu Ustava. Unutarnje ustrojstvo Ustavnog suda uređuje se Poslovnikom Ustavnog suda Republike Hrvatske (u daljnjem tekstu: Poslovnik USUD-a). ${ }^{104}$

Postupak na Ustavnom sudu provode ustavnosudska tijela: (opća) sjednica (u kojoj sudjeluju svi ustavni suci) i vijeća (tročlana i šesteročlana, ovisno o vrsti postupka). Niti u jednoj vrsti ustavnosudskog postupka odluku ne donosi sudac pojedinac.

Na sjednici Ustavnog suda odlučuje se o ocjeni suglasnosti zakona s Ustavom i drugih propisa s Ustavom i zakonom, o sukobu nadležnosti između tijela zakonodavne, izvršne i sudbene vlasti, o odgovornosti predsjednika Republike, o ustavnosti programa i djelovanja političkih stranaka, o ustavnosti i zakonitosti izbora i državnog referenduma, o privremenoj obustavi izvršenja pojedinačnih akata ili radnji koji se poduzimaju na osnovi zakona ili drugog propisa čija se ustavnost odnosno zakonitost ocjenjuje, o izvješćivanju predsjednika Hrvatskoga sabora o pojavama neustavnosti i nezakonitosti te o nadzoru nad donošenjem propisa za izvršenje Ustava, zakona i drugih propisa. Na sjednici se također odlučuje u predmetima u drugim ustavnosudskim predmetima u kojima pri odlučivanju na nadležnom vijeću nije postignuta jednoglasnost. Sve odluke na sjednici donose se većinom glasova ukupnoga broja ustavnih sudaca.

$\mathrm{Na}$ ustavnosudskim vijećima odlučuje se o ustavnim tužbama za zaštitu ljudskih prava i temeljnih sloboda zajamčenih Ustavom (tročlana vijeća za ispitivanje postojanja procesnih pretpostavki i za prethodni ispitni postupak te

101 Kelemen, K., op. cit., str. 1352 i 1357. Isto i Vitale, D., op. cit., str. 3.

102 NN, br. 56/1990, 135/1997, 113/2000, 28/2001, 76/2010, 85/2010 (zadnji pročišćeni tekst) i $5 / 2014$.

$103 \mathrm{NN}$, br. 99/1999, 29/2002 i 49/2002 (pročišćeni tekst).

$104 \mathrm{NN}$, br. 181/2003, 16/2006, 30/2008, 123/2009, 63/2010, 121/2010, 19/2013, 37/2014, 83/2014 (pročišćeni tekst) i 2/2015. 
šesteročlana vijeća za odlučivanje o meritumu), o žalbama protiv odluka Državnoga sudbenog vijeća (u daljnjem tekstu: DSV), o razrješenju sudaca i njihovoj stegovnoj odgovornosti (šesteročlana vijeća) i o izbornim sporovima (tročlana vijeća). Odluke na vijećima donose se jednoglasno, osim u postupcima povodom žalbe protiv odluka DSV-a u kojima Ustavni sud ne provodi postupak kao ustavni već kao žalbeni sud te se odluke donose većinom glasova članova vijeća. Ako se pri glasovanju na vijeću ne postigne jednoglasnost, predmet se upućuje na sjednicu Ustavnog suda. ${ }^{105}$

Po naravi stvari, dakle, mogućnost izdvajanja mišljenja suca Ustavnog suda postoji samo u postupcima u kojima odluku donosi sjednica Ustavnog suda ili vijeće za odlučivanje povodom žalbe na odluku DSV-a, jer se jedino na tim tijelima odluke donose većinom glasova, dok je za donošenje odluka na ostalim ustavnosudskim tijelima potrebna jednoglasnost.

Na temelju odredaba UZUS-a, sudac Ustavnog suda koji se ne slaže s mišljenjem većine može izdvojiti svoje mišljenje, pri čemu ga je dužan pisano obrazložiti (članak 27. stavak 4.) ili glasovati suprotno većini, pri čemu može pisano obrazložiti i objaviti svoje mišljenje (članak 27. stavak 5.).

Slijedom tih odredbi Poslovnik USUD-a također razlikuje ,izdvojeno mišljenje“ od „obrazloženja suprotnog glasovanja“.

Prema njegovim odredbama sudac koji na Sjednici Ustavnog suda izdvoji mišljenje u pogledu izreke i/ili obrazloženja odluke i usmeno ga obrazloži, dužan je izraditi i pisano obrazloženje. Izdvojeno mišljenje može izraditi i više sudaca zajedno (skupno izdvojeno mišljenje, članak 50. stavci 2. i 3.). Izdvajanje mišljenja sudac je dužan usmeno najaviti na sjednici Ustavnog suda nakon što predsjednik Ustavnog suda objavi da je odluka donesena. Pritom sudac koji je najavio izdvojeno mišljenje ima pravo istodobno zahtijevati da se donesena odluka zajedno s izdvojenim mišljenjem objavi i ako objava odluke nije obvezatna. Pisano izdvojeno mišljenje s obrazloženjem sudac je dužan dostaviti predsjedniku Ustavnog suda u roku osam dana od dana donošenja odluke. Do tada se odluka ne otprema radi objave, već samo sudionicima u postupku. Ako izdvojeno mišljenje nije dostavljeno do isteka roka, odluka se otprema radi objave, a naknadno dostavljeno izdvojeno mišljenje uvezuje se u ustavnosudski spis i čini njegov sastavni dio (članak 51.).

$\mathrm{S}$ druge strane, ako sudac glasuje suprotno većini sudaca, ali razloge za to posebno usmeno ne obrazloži na sjednici Ustavnog suda, ima pravo pisano obrazložiti i objaviti svoje mišljenje, pri čemu se na odgovarajući način primjenjuju odredbe o izdvojenom mišljenju (članak 52.).

105 Poslovnikom USUD-a određeno je da rezultati glasovanja i zapisnici o glasovanju spadaju u povjerljivu ustavnosudsku dokumentaciju i stoga nisu dostupni nikome izvan kruga sudaca i ustavnosudskih savjetnika (članak 63. stavci 2. i 3.). Smisao ove odredbe nije jasan, jer se na većini ustavnosudskih tijela, kao što je rečeno, odluke donose jednoglasno, a na onim tijelima na kojim se donose većinom glasova glasovanje je javno. Ipak, vjerojatno po analogiji $\mathrm{s}$ postupanjem redovnih sudova $\mathrm{i}$ inerciji, u praksi se zapisnici o glasovanju spremaju u zatvorene omote uz odluku. 
Razlozi za navedeno razlikovanje izdvojenog mišljenja i obrazloženja suprotnog glasovanja nisu razvidni. Gramatičkim tumačenjem može se samo utvrditi da se izdvojeno mišljenje može odnositi na cijelu odluku, tj. prije svega izreku, a slijedom toga i obrazloženje (suprotno mišljenje, u značenju engleskog izraza dissenting opinion) ili samo na obrazloženje (podudarno odnosno podržavajuće mišljenje, u značenju engleskog izraza concurring opinion) ${ }^{106}$, da ga je potrebno unaprijed najaviti na sjednici te da je sudac u tom slučaju dužan izraditi pisano obrazloženje. Za razliku od toga, obrazloženje suprotnoga glasa po naravi stvari predstavlja suprotno mišljenje u odnosu na izreku (u značenju engleskog izraza dissenting opinion), razlozi se ne moraju obrazložiti na sjednici niti je sudac obvezan izraditi pisano obrazloženje. Međutim, ako sudac želi iznijeti razloge suprotnoga glasovanja i želi da se njegovo obrazloženje objavi, može to učiniti u pisanoj formi. U tom smislu ne samo da između izdvojenoga suprotnog mišljenja i obrazloženja suprotnoga glasovanja nema nikakve sadržajne razlike, osim u različitim nazivima nema niti formalne razlike.

Pritom se u odnosu na suprotno glasovanje otvara pitanje (ne)obveznosti izrade pisanog obrazloženja suprotnoga glasovanja. Kad se sudac ne slaže s većinskom odlukom u tolikoj mjeri da glasuje protiv njezina usvajanja, ne bi li bila njegova obveza prema sudionicima postupka, kolegama sucima kao i prema javnosti objasniti svoje razloge za takav postupak? Biti protiv, a ne obrazložiti zbog čega, nego razloge zadržati samo za sebe, s aspekta sudačke dužnosti jednostavno izgleda kao nedovršen posao, a opravdano može pobuditi i sumnju u pristranost. ${ }^{107}$

UZUS i Poslovnik USUD-a dakle omogućavaju sucima izdvajanje mišljenja i obrazloženje suprotnoga glasovanja. Radi utvrđivanja u kojem opsegu su se suci Ustavnog suda koristili tim mogućnostima u praksi, autor je proveo istraživanje pregledom elektroničke baze podataka i neposrednim uvidom u spise pismohrane Ustavnog suda. Istraživanjem je obuhvaćeno razdoblje od početka djelovanja Ustavnog suda u samostalnoj i neovisnoj Republici Hrvatskoj 1991. godine do kraja 2015. godine.

U razmatranom razdoblju Ustavni sud riješio je ukupno 87.738 predmeta. Pritom je u istom razdoblju izdvojeno ukupno 71 mišljenje u odnosu na 58 odluka ${ }^{108}$, odnosno u 83 predmeta. ${ }^{109}$ (Vidi Tablicu 1.)

106 Vidi supra u poglavlju 2.

107 Usp. mišljenje suca Brennana, supra u poglavlju 4.

$108 \mathrm{U}$ pojedinim predmetima u odnosu na donesenu odluku izjavljeno je više različitih izdvojenih mišljenja.

109 U 11 slučajeva bilo je spojeno više istovrsnih ustavnosudskih predmeta za koje je donesena jedna zajednička odluka. 
Tablica 1. Izdvojena mišljenja po godinama

\begin{tabular}{|c|c|c|c|c|c|c|c|c|c|c|c|c|c|c|c|}
\hline Godina & ڤ் & ลे & $\stackrel{\infty}{2}$ & ஜे & ઠ̊ં & ஜें & 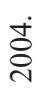 & 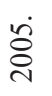 & ஜे & ڤ̊̀ & $\stackrel{\infty}{\stackrel{0}{े}}$ & हें & $\dot{\vec{\Xi}}$ & $\stackrel{i}{\stackrel{i}{*}}$ & $\stackrel{\dot{m}}{\stackrel{i}{N}}$ \\
\hline $\begin{array}{l}\text { Broj izdvojenih } \\
\text { mišljenja }\end{array}$ & 3 & 1 & 3 & 3 & 2 & 5 & 9 & 5 & 14 & 10 & 9 & 2 & 2 & 1 & 2 \\
\hline
\end{tabular}

Od ukupnoga broja izdvojenih mišljenja, u deset slučajeva riječ je o podudarnim mišljenjima, a u 61 slučaju riječ je o suprotnim mišljenjima, od čega su 42 pojedinačna i 19 skupnih izdvojenih mišljenja više sudaca. U tih 19 skupnih izdvojenih mišljenja zbrojeno je sudjelovalo ukupno 54 sudaca.

Pritom su osobito zanimljiva dva predmeta u kojima su se suci izrazito podijelili, tako da je Ustavni sud donio odluku s minimalnim brojem potrebnih glasova uz razmjerno veliki broj suprotnih i podudarnih izdvojenih mišljenja. Riječ je o odlukama U-III-59/06 od 22. studenoga 2006. i U-III-4584/05 od 14. studenoga 2007. ${ }^{110}$ Oba predmeta odnosila su se na zaštitnu mjeru oduzimanja plovila kao sredstva kojim je počinjen prekršaj, izrečenu na temelju Pomorskog zakonika u prekršajnom postupku zbog nedopuštenog prijevoza osoba između hrvatskih luka uz naplatu bez odobrenja nadležnog tijela (tzv. „crnog čartera“). U oba predmeta Ustavni sud je odbio ustavnu tužbu s obrazloženjem da Ustav dopušta ograničavanje ustavnih prava (u konkretnom slučaju vlasništva) te da je izrečena zaštitna mjera propisana zakonom kao obvezatna za tu vrstu prekršaja. U prvom predmetu šestero sudaca zajednički je izdvojilo skupno suprotno mišljenje, a jedan je sudac izdvojio potvrđujuće mišljenje. U drugom predmetu petero sudaca zajednički je izdvojilo skupno suprotno mišljenje (isti kao i u prethodnom predmetu, osim jedne sutkinje koja nije bila nazočna na sjednici), a dvoje sudaca pojedinačno je izdvojilo potvrđujuće mišljenje. U oba predmeta suprotno mišljenje obrazloženo je stajalištem da u konkretnim slučajevima postoji izrazito velika i neprihvatljiva nerazmjernost između težine počinjenog prekršaja i ostvarene nedozvoljene zarade sa zaštitnom mjerom oduzimanja vlasništva jahti, te da je podnositeljima ustavne tužbe oduzeto pravo vlasništva jahti u okolnostima koje su nerazmjerne potrebi za ograničenjem prava vlasništva. ${ }^{111} \mathrm{~S}$ obzirom na snagu argumenata u suprotnim izdvojenim mišljenjima i broju sudaca koji su ih potpisali, može se priličnom vjerojatnošću pretpostaviti da bi u budućnosti ta mišljenja mogla prerasti u većinska i izmijeniti

110 NN, br. $132 / 2006$ i 122/2007.

111 Detaljnije o odluci U-III-59/2006, vidi u Skorupan Wolff, Vesna, Zaštitna mjera oduzimanja plovnog objekta kojim je učinjen prekršaj, Poredbeno pomorsko pravo, god. 46, br. 161, 2007., str. 297-308. Predmet U-III-4584/2005 dobio je nastavak na Europskom sudu za ljudska prava u predmetu Merot $i$ Storitve protiv Hrvatske pokrenutim povodom zahtjeva vlasnika oduzetih jahti koje su bili dali prekršitelju u čarter. Slučaj je međutim završio već u fazi ispitivanja dopuštenosti u kojem su prigovori ocijenjeni nedopuštenim i zahtjevi odbačeni pa do ispitivanja merituma nije ni došlo. Europski sud za ljudska prava, odluka u predmetu Merot d.o.o. i Storitve TIR d.o.o., zahtjevi br. 29426/08 i 29737/08, <https://uredzastupnika. gov.hr/sudska-praksa...>, 15. ožujka 2016. 
ustavnosudsku praksu te dokazati vrijednost tog instituta za razvitak prava na što ukazuju njegovi pobornici. ${ }^{112}$

U odnosu na vrstu ustavnosudskog postupka, najviše je izdvojenih mišljenja u postupcima povodom ustavnih tužbi za zaštitu ljudskih prava i temeljnih sloboda zajamčenih Ustavom (predmeti signatura U-III i U-IIIA) koji su i inače daleko najbrojniji u radu Ustavnog suda, a nakon njih u postupcima za ocjenu suglasnosti zakona s Ustavom (predmeti signature U-I) i drugih propisa s Ustavom i zakonom (predmeti signature U-II) te u postupcima rješavanja izbornih sporova (predmeti signature U-VIIA), postupcima privremene obustave izvršenja pojedinačnih akata ili radnji koji se poduzimaju na osnovi zakona ili drugog propisa čija se ustavnost ili zakonitost ocjenjuje (predmeti signature U-VIII) i postupcima u povodu žalbi protiv odluka Državnog sudbenog vijeća o stegovnoj odgovornosti sudaca (predmeti signature U-IXA), dok u drugim ustavnosudskim postupcima izdvojenih mišljenja nije bilo. (Vidi tablicu 2.)

Tablica 2. Izdvojena mišljenja po pojedinim ustavnosudskim postupcima

\begin{tabular}{|l|c|c|c|c|c|c|c|}
\hline $\begin{array}{l}\text { Vrsta postupka } \\
\text { (signatura) }\end{array}$ & U-I & U-II & U-III & U-IIIA & U-VIIA & U-VIII & U-IXA \\
\hline $\begin{array}{l}\text { Broj izdvojenih } \\
\text { mišljenja }\end{array}$ & 16 & 7 & 41 & 4 & 1 & 1 & 1 \\
\hline
\end{tabular}

U razmatranom razdoblju dužnost suca Ustavnog suda obavljale su 33 osobe. Od toga broja 25 sudaca koristili su pravo na izdvajanje mišljenja, a osmero sudaca (četvrtina) tijekom osmogodišnjeg mandata ni u jednom predmetu nisu izdvojili svoje mišljenje, bilo pojedinačno ili zajedno s drugim sucima. Najveći broj izdvojenih mišljenja po pojedinom sucu iznosi ukupno 18 (dva pojedinačna podržavajuća, osam pojedinačnih suprotnih i osam skupnih suprotnih). (Vidi tablicu 3.)

Tablica 3. Ustavni suci prema broju izdvojenih mišljenja

\begin{tabular}{|l|c|c|c|c|c|c|c|c|c|c|c|c|}
\hline Broj sudaca & 1 & 1 & 1 & 2 & 1 & 1 & 1 & 1 & 2 & 4 & 10 & 8 \\
\hline $\begin{array}{l}\text { Broj izdvojenih } \\
\text { mišljenja }\end{array}$ & 18 & 11 & 10 & 9 & 8 & 7 & 6 & 4 & 3 & 2 & 1 & 0 \\
\hline
\end{tabular}

Sva skupna izdvojena mišljenja koje je izjavilo dvoje ili više sudaca jesu suprotna mišljenja i u njima je ukupno zastupljeno 54 sudaca. (Vidi tablicu 4.)

Tablica 4. Skupna izdvojena mišljenja prema broju sudaca

\begin{tabular}{|l|l|l|l|l|l|}
\hline Broj sudaca & 2 & 3 & 4 & 5 & 6 \\
\hline $\begin{array}{l}\text { Broj skupnih } \\
\text { izdvojenih } \\
\text { mišljenja }\end{array}$ & 11 & 3 & 3 & 1 & 1 \\
\hline
\end{tabular}

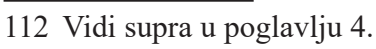


Izdvojena mišljenja sudaca u pravilu se objavljuju zajedno s odlukom Ustavnog suda i to u Narodnim novinama i na mrežnoj (internetskoj) stranici Ustavnog suda (www.usud.hr). No ta praksa nije sasvim dosljedna. Naime, od ukupno 58 odluka uz koje postoji i izdvojeno mišljenje, u Narodnim novinama nisu objavljene tri odluke pa tako ni izdvojena mišljenja, a u jednom predmetu objavljena je samo odluka bez izdvojenog mišljenja. Na mrežnoj stranici Ustavnog suda u rubrici Praksa Ustavnog suda objavljene su 43 odluke i uz njih izdvojena mišljenja.

U odnosu na pisano obrazloženje suprotnog glasovanja i njegovu objavu tu je mogućnost koristilo samo sedmero sudaca i to u odnosu na šest odluka odnosno 21 predmet $^{113}$ : u tri slučaja ocjene suglasnosti zakona s Ustavom, dva slučaja ocjene suglasnosti drugih propisa s Ustavom i zakonom te u jednom slučaju u postupku povodom ustavne tužbe za zaštitu ljudskih prava i temeljnih sloboda zajamčenih Ustavom. U pet slučajeva bila je riječ o pojedinačnom obrazloženju suprotnog glasovanja, a u jednom slučaju u zajedničkom obrazloženju troje sudaca (vidi Tablicu 5.). Sve su te odluke donesene u razdoblju od 2000. do 2007. godine. Pet odluka objavljeno je zajedno s obrazloženjem suprotnoga glasovanja u Narodnim novinama, a jedna od njih i na mrežnoj stranici Ustavnog suda, dok jedna nije objavljena.

Tablica 5. Ustavni suci prema broju obrazloženja suprotnoga glasovanja

\begin{tabular}{|c|c|c|c|}
\hline Broj sudaca & 1 & 2 & 1 \\
\hline $\begin{array}{c}\text { Broj obrazloženja } \\
\text { suprotnoga } \\
\text { glasovanja }\end{array}$ & $\begin{array}{c}3 \\
\text { (pojedinačna) }\end{array}$ & $\begin{array}{c}2 \\
\text { (po 1 pojedinačno i 1 } \\
\text { zajedničko) }\end{array}$ & $\begin{array}{c}1 \\
\text { (zajedničko) }\end{array}$ \\
\hline
\end{tabular}

Kad se zbroje izdvojena mišljenja i obrazloženja suprotnoga glasovanja (koja u biti nisu ništa drugo nego suprotna izdvojena mišljenja) dolazi se do rezultata od ukupno 77 pisanih očitovanja sudaca o razlozima njihova neslaganja s većinom, a koja se odnose na 64 odluke odnosno 104 predmeta $^{114}$, što čini tek $0,1 \%$ riješenih predmeta (87.738).

Osim toga, Ustavni sud je u posljednje dvije godine donio odluke u 12.906 predmeta, od čega u 23 predmeta odluke nisu donesene jednoglasno već većinom glasova sudaca, ali pritom nije bilo ni jednog izdvojenog mišljenja niti obrazloženja suprotnoga glasa.

Iz navedenih podataka proizlazi da se u praksi Ustavnog suda mogućnost izdvajanja mišljenja u odnosu na donesenu odluku suda iznimno malo koristi, iako mjerodavni propisi to izričito dopuštaju. To osobito vrijedi za razdoblje od 2009. godine do danas.

Naime, pregled po godinama pokazuje da je posljednji relativno veći broj izdvojenih mišljenja bio 2008. godine, od kada njihov broj tijekom četiri naredne 
godine ne prelazi dva izdvojena mišljenja godišnje, a posljednje dvije godine ih uopće nema. Ti podatci, kao i podatci o tomu da je u posljednjih četiri godine Ustavni sud riješio ukupno 28.577 predmeta, od kojih u samo 49 slučajeva (72 predmeta, odnosno $0,25 \%$ ) odluka nije donesena jednoglasno, upućuju na zaključak da je Ustavni sud u svom postupanju prihvatio politiku nastojanja postizanja jednoglasnosti u donošenju odluka.

U kojoj mjeri takvo postupanje pridonosi jačanju autoriteta suda te razumijevanju, uvjerljivosti i prihvaćanju njegovih odluka teško je procijeniti. Činjenica je da broj podnesaka za pokretanje ustavnosudskih postupaka koje Ustavni sud zaprima ne opada, što znači da građani ne gube povjerenje u njega. S druge strane, pojedine institucije, mediji i pojedinci nerijetko su izrazito loše ocjenjivali rad Ustavnog suda i pojedine njegove odluke. Stručna javnost također ne ocjenjuje pozitivno izostanak izdvojenih mišljenja u ustavnosudskoj praksi. ${ }^{115}$ Osim toga, činjenica je da je na kraju 2015. godine na Ustavnom sudu bilo 530 neriješenih predmeta starijih od tri godine. Premda se taj zaostatak vjerojatno može opravdati složenošću predmeta, moguće je da je on u određenom dijelu nastao i kao posljedica utroška vremena i energije u nastojanju i upornosti da se odluke donesu jednoglasno.

Iako zasigurno postoje snažni razlozi za nastojanje da se u donošenju odluka postigne jednoglasnost, oni bi se teško mogli opravdati ako to ima negativan utjecaj na brzinu rješavanja predmeta i time na djelotvornost ustavnosudske zaštite. Osim toga, jasno je da jednoglasnost nužno ne znači i stvarnu potpunu podudarnost razmišljanja sudaca. Nedvojbeno je da u određenom broju predmeta, osobito onih složenih, jednoglasno donesena odluka zapravo predstavlja kompromis u kojem dolazi do odustajanja od određenih pojedinačnih osobnih stajališta i uvjerenja. U tom smislu može se špekulirati o tomu bi li ugled Ustavnog suda u cjelini i ustavnih sudaca pojedinačno možda bio snažniji kad bi u njegovoj praksi bilo više izdvojenih mišljenja.

115 Primjerice Smerdel smatra da: „Takvim pristupom Ustavni sud šalje pogrešnu poruku pravničkoj javnosti! Bit je te poruke »budite oprezni, na području ustavnog prava različitost je (još uvijek) nepoželjna i opasna«.“, Smerdel, B., O sudskoj..., cit., str. 3. Barić se pita kako je moguće da Ustavni sud kontinuirano donosi odluke jednoglasno bez izdvojenih mišljenja i: „smatra da bi ustavni suci morali imati stručne kvalifikacije i kredibilitet koji bi im bio podloga da s osobnim stavom koji nije podudaran s većinom istupe i pod svojim imenom navedu da razmišljaju drugačije o nekom pitanju.“ Barić, S. u članku Ivanke Toma „Može li Hrvatska bez Ustavnog suda?“, objavljenog u Jutarnjem listu od 7. studenoga 2015. 


\section{ZAKLJUČAK}

Mogućnost izdvajanja mišljenja suca koji se u cijelosti ili djelomično ne slaže s odlukom većine sudaca i njegova objava zajedno sa sudskom odlukom tradicionalno predstavljaju obilježje common law sustava. Međutim, u novije vrijeme ono se dopušta i u sve većem broju država sa sustavom civilnog prava, osobito u postupcima ustavnoga nadzora.

Izdvojeno mišljenje suca, osobito ono suprotno izreci sudske odluke (dissent), nesporno utječe na uvjerljivost $\mathrm{i}$ vjerodostojnost konkretne odluke kao i na pravnu sigurnost općenito. S aspekta održavanja vanjskog autoriteta suda i dobrih međusobnih odnosa unutar njega poželjno je da se odluke donose konsenzusom sudaca ili barem da se eventualna nepomirljiva neslaganja ne objavljuju izvan profesionalnoga kruga.

S druge strane, jednako je tako nedvojbeno da nedopuštanje izdvajanja mišljenja predstavlja bitno ograničenje slobode izražavanja mišljenja suca i njegove neovisnosti, što slabi njegovu motiviranost i samopoštovanje te ga onemogućava u nastojanju da utječe na budući razvoj i promjene u sferi pravnog razmišljanja i primjene prava.

U tom smislu institut izdvojenog mišljenja zapravo u sebi nosi suprotnost, jer ovisno o dosegnutoj razni razvoja konkretnog društva i povjerenja u njegove institucije objektivno može potkopati ili ojačati autoritet suda i prihvaćanje njegovih odluka.

Premda se argumenti protiv instituta izdvojenog mišljenja ne mogu poreći, u ocjeni njegove vrijednosti i opravdanosti ipak prevladavaju razlozi koji mu govore u prilog: jačanje osobnog integriteta i neovisnosti suca, a time i suda, poboljšanje kvalitete sudskih odluka, pridonošenje transparentnosti sudskoga postupka i stvaranje podloge za budući razvitak prava. Pritom bi taj institut trebalo koristiti ograničeno i to samo u predmetima koji zbog svog načelnog interesa to zaslužuju.

Iako je u postupcima pred Ustavnim sudom Republike Hrvatske izdvajanje mišljenja i obrazlaganje suprotnoga glasovanja, kao i njihovo objavljivanje izričito dopušteno, praksa pokazuje priličnu suzdržanost ustavnih sudaca u korištenju te mogućnosti. Za buduće postupanje Ustavnog suda bilo bi korisno istražiti je li to i u kojoj mjeri utjecalo na njegov ugled u javnosti. 


\section{Summary}

\section{SEPARATE OPINION IN JUDICIAL PROCEEDINGS AND CROATIAN CONSTITUTIONAL COURT'S EXPERIENCE}

The topic of this paper is the legal institute of separate (dissenting and concurring) opinion of a judge who disagrees with the majority decision of a court chamber. Even though this institute has traditionally been considered a common law feature, most civil law countries recognise it, especially in constitutional matters. The paper deals with this institute not only from historical and comparative perspectives, but also from the legal and theoretical one. The author points to the reasons in favour of separate opinions such as freedom of speech and judicial independence, as well as to the reasons against it, e.g., legal certainty, clarity and persuasiveness of court judgements and also to their impact on integrity and reputation of courts. In the Croatian legal system separate opinions are in principle allowed at the level of regular courts, but it is not permitted to make them public. At the Constitutional Court of the Republic of Croatia separate opinions and presentation of the reasons for voting contrary to the majority as well as their publication are fully permitted. However, the Constitutional Court's practice shows considerable reluctance of Constitutional Court judges to use these institutes.

Key words: court decision, separate opinion, dissent, Constitutional court.

\section{Zusammensetzung}

\section{SONDERGUTACHTEN VON GERICHTVERFAHREN UND PRAKTIKEN DES BUNDESVERFASSUNGSGERICHTES DER REPUBLIK KROATIEN}

Der Gegenstand dieses Artikels ist das rechtliche Institut des Sondergutachtens des Richters, der nicht mit dem Beschluss einig ist, für den die Mehrheit der Richter des kollegialen Rechtskörpers abgestimmt hat, und zwar weder mit seinem Urteilsspruch noch mit dessen Begründung. Obwohl die Möglichkeit des Sondergutachtens traditionell als Eigenschaft der Staaten des commom law Systems betrachtet wird, existiert sie heutzutage auch in der Mehrheit der Staaten des Kontinentalsystems, besonders bei Bundesverfassungsgerichten. Das Sondergutachten wird aus dem historisch-komparativen und rechtlich-theoretischen Aspekt betrachtet.

Es wird auf Gründe zugunsten der Gestattung des Sondergutachtens angewiesen, wie Meinungsfreiheiten und Richterselbstständigkeit aber auf Gründe die dagegen sind, wie zum Beispiel Rechtssicherheit, Klarheit und Glaubwürdigkeit 
der Richterentscheidungen und Einfluss auf die Integrität und Autorität des Gerichtes. Im kroatischen Rechtswesen sind Sondergutachten in der ordentlichen Jurisdiktion in der Regel erlaubt aber nicht ihre Veröffentlichung, während beim Bundesverfassungsgericht das Sondergutachten explizite erlaubt ist, sowohl die Begründung der entgegengesetzten Abstimmung als auch deren Veröffentlichung. Die Praxis des Bundesverfassungsgerichtes zeigt jedoch ziemliche Zurückhaltung der Richter der Bundesverfassungsgerichte bei der Benützung dieser Möglichkeit.

Schlüsselwörter: Gerichtsbeschluss, Sondergutachten, entgegengesetzte Abstimmung, Bundesverfassungsgericht.

Riassunto

\section{OPINIONE DISSENZIENTE NEI PROCEDIMENTI GIUDIZIALI E PRASSI DELLA CORTE COSTITUZIONALE DELLA REPUBBLICA DI CROAZIA}

Oggetto di questo articolo è l'istituto giuridico dell'opinione dissenziente del giudice che non è d'accordo con la decisione votata dalla maggioranza dei giudici dell'organo collegiale, sia che si tratti del suo dispositivo, che della motivazione. Sebbene la possibilità di esprimere opinione dissenziente venga tradizionalmente considerata una caratteristica dei paesi di common law, essa oggi esiste nella maggiore parte dei paesi di diritto continentale, in ispecie nelle corti costituzionali. L'opinione dissenziente viene esaminata sotto il profilo storico-comparato e sotto il profilo giuridico-teorico. Si indicano le ragioni a favore dell'ammissibilità delle opinioni dissenzienti, quali sono la libertà di manifestazione del pensiero e l'autonomia giudiziaria, ma anche quelle contrarie come, ad esempio, la certezza del diritto, la chiarezza e la persuasività delle sentenze, come pure l'influenza sull'integrità e sulla reputazione della corte. Nel sistema giuridico croato nel contenzioso ordinario di regola le opinioni dissenzienti sono ammesse, ma non altresì la loro pubblicazione; mentre nei giudizi della Corte costituzionale è espressamente consentita l'opinione dissenziente e la motivazione della votazione contraria, così come la loro pubblicazione. La giurisprudenza costituzionale, tuttavia, mostra un atteggiamento sostenuto dei giudici costituzionali nell'utilizzo di tale opportunità.

Parole chiave: decisione giudiziale, opinione dissenziente, voto contrario, corte costituzionale. 